\title{
Exploring the DPP-IV Inhibitory, Antioxidant and Antibacterial Potential of Ovine "Scotta" Hydrolysates
}

\author{
Roberto Cabizza ${ }^{1}$, Francesco Fancello ${ }^{1}\left(\mathbb{D}\right.$, Giacomo Luigi Petretto $\left.^{2} \mathbb{(}\right)$, Roberta Addis ${ }^{2}$, Salvatore Pisanu ${ }^{3}$, \\ Daniela Pagnozzi $^{3}\left(\mathbb{D}\right.$, Antonio Piga $^{1}$ (D) and Pietro Paolo Urgeghe ${ }^{1, *(\mathbb{D})}$ \\ 1 Dipartimento di Agraria, Università degli Studi di Sassari, Viale Italia 39/A, 07100 Sassari, Italy; \\ rcabizza@uniss.it (R.C.); fancello@uniss.it (F.F.); pigaa@uniss.it (A.P.) \\ 2 Dipartimento di Chimica e Farmacia, Università degli Studi di Sassari, Via Muroni 23/A, 07100 Sassari, Italy; \\ gpetretto@uniss.it (G.L.P.); raddis@uniss.it (R.A.) \\ 3 Porto Conte Ricerche SRL, Loc Tramariglio, 07041 Alghero, Italy; pisanu@portocontericerche.it (S.P.); \\ pagnozzi@portocontericerche.it (D.P.) \\ * Correspondence: paolou@uniss.it; Tel.: +39-0792-29378
}

\section{check for}

updates

Citation: Cabizza, R.; Fancello, F.; Petretto, G.L.; Addis, R.; Pisanu, S.; Pagnozzi, D.; Piga, A.; Urgeghe, P.P. Exploring the DPP-IV Inhibitory, Antioxidant and Antibacterial Potential of Ovine "Scotta" Hydrolysates. Foods 2021, 10, 3137. https://doi.org/10.3390/ foods10123137

Academic Editor: Manuel Castillo Zambudio

Received: 23 November 2021 Accepted: 14 December 2021 Published: 17 December 2021

Publisher's Note: MDPI stays neutral with regard to jurisdictional claims in published maps and institutional affiliations.

Copyright: (C) 2021 by the authors Licensee MDPI, Basel, Switzerland. This article is an open access article distributed under the terms and conditions of the Creative Commons Attribution (CC BY) license (https:// creativecommons.org/licenses/by/ $4.0 /)$.

\begin{abstract}
The aim of this work was to valorize the by-product derived from the ricotta cheese process (scotta). In this study, ovine scotta was concentrated by ultrafiltration and then subjected to enzymatic hydrolyses using proteases of both vegetable $\left(4 \% \mathrm{E}: \mathrm{S}, 4 \mathrm{~h}, 50^{\circ} \mathrm{C}\right)$ and animal origin $(4 \% \mathrm{E}: \mathrm{S}$, $4 \mathrm{~h}, 40^{\circ} \mathrm{C}$ ). The DPP-IV inhibitory, antioxidant, and antibacterial activities of hydrolysates from bromelain (BSPH) and pancreatin (PSPH) were measured in vitro. Both the obtained hydrolysates showed a significantly higher DPP-IV inhibitory activity compared to the control. In particular, BSPH proved to be more effective than PSPH ( $\mathrm{IC}_{50} 8.5 \pm 0.2$ vs. $\left.13 \pm 1 \mathrm{mg} \mathrm{mL}^{-1}\right)$. Moreover, $\mathrm{BSPH}$ showed the best antioxidant power, while PSPH was more able to produce low-MW peptides. BSPH and PSPH hydrolysates showed a variable but slightly inhibitory effect depending on the species or strain of bacteria tested. BSPH and PSPH samples were separated by gel permeation chromatography (GPC). LC-MS/MS analysis of selected GPC fractions allowed identification of differential peptides. Among the peptides 388 were more abundant in BSPH than in the CTRL groups, 667 were more abundant in the PSPH group compared to CTRL, and 97 and 75 of them contained sequences with a reported biological activity, respectively.
\end{abstract}

Keywords: ovine scotta; bioactive peptides; bromelain; pancreatin; dipeptidyl peptidase IV inhibition; ovine second whey cheese; enzymatic hydrolysis

\section{Introduction}

"Scotta", also called "ricotta cheese exhaust whey" (RCEW) or "second cheese whey" (SCW) is the residual liquid by-product of the ricotta cheese production process, obtained by thermal flocculation of whey proteins, and heating the whey at a temperature of 85-90 ${ }^{\circ} \mathrm{C}$ and $78-85^{\circ} \mathrm{C}$ for bovine or buffalo and ovine or goat whey, respectively [1]. Whey composition, the treatments performed during ricotta production process (i.e., adding milk, whey protein extraction method), and ricotta yield (depending on the temperature of protein coagulation, $\mathrm{pH}$, and ionic strength of the whey) are the main factors that affect the physicochemical characteristics of scotta [2].

In Italy, scotta is mainly produced from bovine and ovine milk and, in less quantity, from buffalo and goat milk. During 2019 about 900,000 tons [3] of whey were transformed into ricotta cheese in Italy, representing about $16 \%$ of total whey produced, giving rise to more than 750,000 tons of scotta.

The production of scotta from ovine whey is mainly concentrated in Sardinia, which hosts about $22 \%$ of Italian dairy ewes [ 4 ] and where is produced more than $65 \%$ of Italian ovine milk. The Sardinian dairy system produces about 320,000 tons of ovine milk [5], which is almost completely destined for cheese production. About 12,000 tons of ricotta 
are produced in Sardinia, with a potential production of more than 250,000 tons of scotta. The disposal of scotta poses serious environmental concerns due to its high biochemical oxygen (BOD) and chemical oxygen demand (COD) [6-8]. Therefore, its valorization is becoming crucial for the dairy industry.

For many decades whey, and especially scotta, were underused or treated as waste, due to poor knowledge of their valuable components and the unavailability of adequate technologies to valorize such components. Over the years, several approaches to its valorization have been developed [9-11], since scotta still retains significant amount of useful compounds from whey, such as lactose, minerals, oligosaccharides, vitamins, proteins, soluble peptides, and free amino acids [9]. Scotta has been employed using biotechnological approaches as a growth substrate for some selected Lactic Acid Bacteria (LAB) for the production of lactic acid [12], or yeasts such as Chlorella protothecoides for the production of carotenoids, chlorophyll [13], and bioethanol [6,14], as ingredient to fortify ricotta, including bioactive peptides with antioxidant and anti-tyrosinase activities [15], bioactive peptides with angiotensin-I-converting enzyme (ACE)-inhibitory [16] biodegradable bioplastic [17], fermented drink [18] and hydrogen [19,20].

Furthermore, the interest in the application of enzymes of animals or plant sources applied to food matrices has grown during over the years [21,22], with the aim of valorizing by-products and reducing environmental impact [23]. The hydrolysis of whey proteins is a widespread practice, and the hydrolyzed whey protein (WPH) has had an important impact as functional or nutraceutical ingredient. WPH is produced by enzymatic hydrolysis of whey proteins, mainly from whey protein concentrates (WPC) or isolates (WPI), which leads to an increase in solubility and digestibility, reducing whey protein allergenic properties. Peptides obtained by enzymatic hydrolysis of whey proteins have shown interesting biological activities, with potential benefit for human health [24,25]; however, scientific studies specifically addressed to the valorization of scotta proteins and derived peptides are still poor [15].

Recently, several authors studied the potential of whey protein hydrolysates as inhibitors against dipeptidyl peptidase-4 (DPP-IV) [26-29]. DPPI-IV inhibitors play a key role in the treatments of type 2 diabetes (T2D), a worldwide diffused disease that affects 415 million people and in Italy accounts for more than 3 million patients, i.e., about $5 \%$ of the population [30].

The DPP-IV inhibitors adopted as oral antidiabetic agents act by promoting glucose homeostasis through the inhibition of the enzyme DPP-IV involved in the mechanism of degradation of glucose-dependent insulinotropic polypeptide (GIP) and glucagon-like peptide-1 (GLP-1), two key glucoregulatory hormones. DPP-IV inhibitors can reduce glucagon levels and at the same time stimulate insulin release.

The antioxidant potential of peptides derived from milk and whey proteins is well-reviewed [31]. However, up to now, just two works have focused on the antioxidant activity of scotta. Sommella et al. [11] reported bovine scotta peptides with antioxidant activity derived from $\alpha$ s1-casein and $\beta$-casein. Monari et al. [15] tested different proteases on bovine scotta, observing in vitro the antioxidant potential of the obtained hydrolysates.

The antibacterial activity of biopeptides encrypted into the protein fraction of ovine milk and whey has been already shown [32-34]. Several peptides of the C-terminal region of the ovine $\alpha$ s2-casein were shown to possess antibacterial activity against Gram-positive and Gram-negative bacteria, with the first group of bacteria more susceptible than the second group [33]. El-Zahar et al. [32] found that the peptic hydrolysates of whey protein inhibited, in a dose-dependent manner, the growth of Escherichia coli, Bacillus subtilis, and Staphylococcus aureus. Regarding scotta, recent work $[11,15]$ showed the presence of several antibacterial peptides in the protein fraction of scotta.

Regarding the available proteases, bromelain and pancreatin were previously applied in the hydrolysis of dairy products and by-products to produce peptides with DPP-IV inhibitory [35] and antioxidant activity [15]. In addition, bromelain was reported to release antibacterial peptides from goat milk and whey [36]. 
While the literature has been mainly focused on the bioactive properties of peptides obtained from milk and whey proteins, the available data on scotta are limited to the bovine source [9] and, to the best of our knowledge, the present study is the first conducted on the ovine scotta as a potential source of bioactive peptides. Conversely, this matrix could represent an important source of such peptides, due to its higher amount of nitrogen, compared with bovine whey and scotta. The research conducted in this field could lead both to an adequate valorization of this by-product and an improvement of the sustainability of the dairy farms. Therefore, the aim of the present study was to evaluate the possibility of producing peptides with DPP-IV inhibitory, antioxidant and antibacterial activities from ultrafiltered ovine scotta by enzymatic hydrolysis with bromelain (BSPH), and pancreatin (PSPH), and evaluate their biological activity by in vitro tests. Furthermore, an in-depth characterization of peptide mixtures obtained from the hydrolysis with the two enzymes by gel permeation chromatography (GPC) and LC-MS/MS was performed.

\section{Materials and Methods}

\subsection{Chemicals and Reagents}

Analytical grade chemicals were obtained from Carlo Erba (Milano, Italy). Bromelain was obtained from Nutraceutica (Bologna, Italy) (2400 GDU g ${ }^{-1}$ ) and from Enzyme Development Corporation (New York, NY, USA). Pancreatin from porcine pancreas (4 USP) was purchased from Sigma-Aldrich (St. Louis, MI, USA).

Synthetic peptides used for Gel Permeation Chromatography (GPC) calibration were bought from Sigma-Aldrich (St. Louis, MI, USA) (i.e., bovine serum albumin (BSA), $\beta$-Lactoglobulin $(\beta$-Lg), $\alpha$-lactalbumin $(\alpha$-La), aprotinin, bacitracin, tetrapeptide (Leu-TrpMet-Arg), Asp-Glu, Tyr).

\subsection{Scotta Concentrate Preparation}

Ovine scotta was freshly collected from a dairy plant located in north Sardinia (Italy) after the manufacturing of ovine Ricotta cheese, and immediately refrigerated to $4{ }^{\circ} \mathrm{C}$, delivered to the lab and stored at $-20^{\circ} \mathrm{C}$. Scotta was thawed to $20^{\circ} \mathrm{C}$ immediately before the concentration step. The mean chemical composition, determined according to the literature [37] was as follows: $\mathrm{pH} 6.19 \pm 0.11$; total solids, $6.73 \pm 0.28 \%(w / w)$; fat, $0.05 \pm 0.02 \%(w / w)$; total nitrogen (TN), $0.14 \pm 0.01 \%(w / w)$; nitrogen soluble in water (NS), $0.08 \pm 0.05 \%(w / w)$; non-protein nitrogen (NPN), $0.07 \pm 0.05 \%(w / w)$; ash, $0.34 \pm 0.23 \%(w / w)$.

Scotta (5 L) underwent a preliminary continuous skimming at $15,000 \times g$ using a lab-scale cream separator (TLE 100, Tecnolatte, Lodi, Italy), then was consecutively filtered through 5, 1.2, and $0.65 \mu \mathrm{m}$ on conventional cartridge filters (Sartopure PP3 Midicap, Sartorius, Goettingen, Germany) with a surface area of $0.21,0.15$, and $0.15 \mathrm{~m}^{2}$ respectively, fed by a SartoJet Membrane Pump (Sartorius, Goettingen, Germany). The $0.65 \mu \mathrm{m}$ filtered skimmed scotta underwent tangential filtration at $20{ }^{\circ} \mathrm{C}$ through a $10 \mathrm{kDa}$ Hydrosart membrane (Sartocon Slice Cassette, Sartorius, Goettingen, Germany), keeping a constant transmembrane pressure of 0.5 bar, and monitoring the removed permeate weight, which was precalculated in order to obtain a nitrogen concentration factor of $4 \times$. The retentate was then reconstituted to the original weight by adding ultrapure (UP) water and subsequently underwent a diafiltration step using the same membrane, in order to reduce the mineral fraction and lactose. The collected retentate was sampled at the end of the process for total nitrogen (NT) determination and then stored at $-20{ }^{\circ} \mathrm{C}$ until the subsequent hydrolysis steps.

\subsection{Enzymatic Hydrolysis of Retentate Scotta Samples}

The retentate obtained in Section 2.2, with a total nitrogen of $0.50 \pm 0.01 \%(w / w)$, was split between two experiments to be hydrolyzed with bromelain (BSPH) and pancreatin (PSPH), respectively. For each experiment, three hydrolyses on $50 \mathrm{~g}(n=3)$ of retentate were performed. Lab-scale enzymatic reactions were performed for $4 \mathrm{~h}$. Enzymatic hydrolysis were performed, as recommended by the manufacturer, at $50{ }^{\circ} \mathrm{C}$ for bromelain and at $40{ }^{\circ} \mathrm{C}$ 
for pancreatin. The enzyme-substrate (E:S) ratio was fixed at 4\% (enzyme weight to protein weight) for both experimental groups. Further three $50 \mathrm{~g}$ retentate control samples (CTRL) underwent the same procedure without enzyme addition, setting the temperature and duration to $50{ }^{\circ} \mathrm{C}$ and $4 \mathrm{~h}$, respectively. The enzymatic reactions were performed in a water bath at constant temperature $\left( \pm 0.05^{\circ} \mathrm{C}\right)$ and continuous magnetic stirring at $500 \mathrm{rpm}$ using an AREX-6 Digital PRO Hot Plate Stirrer (Velp Scientific, Bohemia, NY, USA) equipped with a VTF EVO digital thermoregulator. All the reactions were stopped by heating the mixtures at $90{ }^{\circ} \mathrm{C}$ for $10 \mathrm{~min}$ to inactivate the proteases. Afterward, the mixtures were centrifuged twice at $14,000 \times g$ (Neya 16 R, Remi Elektrotechnki LTD, Vasai, India) for 15 min at $4{ }^{\circ} \mathrm{C}$, and the precipitate was discarded. The obtained supernatants of bromelain scotta protein hydrolysate (BSPH), pancreatin scotta protein hydrolysate (PSPH) and of the control were freeze-dried (Labconco, Kansas City, MO, USA) and stored at $-20{ }^{\circ} \mathrm{C}$ until further analysis, such as DPP-IV inhibition, antioxidant capacity and an antibacterial assay, as well as gel permeation chromatography (GPC) and LC-MS/MS characterization.

\subsection{DPP-IV Inhibitory Activity}

A DPP-IV drug discovery kit was used to measure the ability of hydrolysates to inhibit DPP-IV activity (Enzo Life Sciences Inc., Farmingdale, New York, NY, USA). The assays were conducted according to the manufacturer's instructions. Briefly, the kit contained human recombinant DPP-IV enzyme, a chromogenic substrate (H-Gly-Pro-pNA, $\mathrm{MW}=328.8,10 \mathrm{mM}$ in DMSO), a calibration standard (p-nitroaniline, $\mathrm{MW}=138$, in assay buffer), an inhibitor as positive control (P32/98, MW = 260.4, $1 \mathrm{mM}$ in DMSO), and an assay buffer (50 mM Tris, $\mathrm{pH} 7.5$ ). All the reagents of the kit were stored at $-70{ }^{\circ} \mathrm{C}$; the analyses were conducted at room temperature. The freeze-dried protein hydrolysates were dispersed in ultrapure water in concentrations from 0.78 to $12.5 \mathrm{mg} \mathrm{mL}^{-1}$. Assays were performed at $37^{\circ} \mathrm{C}$, in a 96 -well microplate provided by the manufacturer and the reading was performed in a microplate reader every minute for a total of $30 \mathrm{~min}$ at $\lambda 405 \mathrm{~nm}$. Finally, absorbance values were plotted against time, and the "best fit" lines for data points and slope of the curves were obtained. Two technical replicates for each sample were performed. The \% of inhibition was calculated with the formula:

$\%$ activity remaining $($ with inhibitor $)=($ slope of inhibitor sample $/$ control slope $) \times 100$

The obtained data were analyzed by a one-way analysis of variance (ANOVA) using a Statgraphics Centurion XVI for Windows software package (version 16.2.04; Statpoint Technologies, Inc. Warrenton, Virginia, VA, USA). Fisher's least significant differences (LSD) test was applied to assess the difference between each pair of means $(p<0.05)$.

\subsection{ABTS Radical Scavenging Activity}

Antioxidant capacity was evaluated by colorimetric assay measuring the activity of the sample to scavenge the radical ABTS according to the method described by Petretto et al. [38]. The ABTS radical scavenging activity is based on the production of the radical cation (ABTS + ), prepared by reacting ABTS and potassium persulfate $(2.45 \mathrm{mM})$ to reach a final concentration of $7 \mathrm{mM}$. Briefly, the solution obtained was kept in the dark at $25{ }^{\circ} \mathrm{C}$ for $12-16 \mathrm{~h}$ before the analysis. The ABTS radical solution was properly diluted with ethanol $70 \%$ to obtain an absorbance $(\lambda=734 \mathrm{~nm})$ of $0.7 \pm 0.02$. The freeze-dried protein hydrolysates were dispersed in ultrapure water at concentrations ranging from 0.78 to $12.5 \mathrm{mg} \mathrm{mL}^{-1}$. The reduction of radical ABTS was monitored at the start and after $50 \mathrm{~min}$ from the beginning of the reaction. Two technical replicates for each sample were performed. The antioxidant power of samples was expressed as a percentage of inhibition, and an $\mathrm{IC}_{50}$ value was calculated from the regression curve plotting different concentrations of hydrolysates against the percentage of activity, and expressed as the mean \pm SD. Data were analyzed as described in Section 2.4. 


\subsection{Antibacterial Assays}

The antibacterial activity of scotta hydrolysates was tested against six bacterial strains (see Table 1) belonging to three different species, namely, Listeria monocytogenes (four strains), Staphylococcus aureus and Salmonella bongori. The strains, stored at $-80^{\circ} \mathrm{C}$, were thawed and precultured in Brain Heart infusion broth medium (BHI, WVR, Milano, Italy) for $24 \mathrm{~h}$ at $37^{\circ} \mathrm{C}$. Overnight cultures were then used to prepare microbial inoculation used for the test. One milliliter of overnight culture was centrifuged at $14,000 \times g$ for $2 \mathrm{~min}$, then the pellets were resuspended in saline solution until reaching 0.2 optical density (OD) $\left(\sim 8 \log 10 \mathrm{CFU} \mathrm{mL}^{-1}\right)$.

Table 1. List of microorganisms, medium and culture condition for testing the antimicrobial activity of enzymatic hydrolysate of Scotta ${ }^{1}$.

\begin{tabular}{cccc}
\hline Tested Organisms & Source & Medium & $\begin{array}{c}\text { Temperature and } \\
\text { Time of Incubation }\end{array}$ \\
\hline Staphylococcus aureus 20,231 DSMZ & DSMZ & BHI & $37^{\circ} \mathrm{C} \times 24 \mathrm{~h}$ \\
\hline $\begin{array}{c}\text { Listeria monocytogenes B } \\
\text { Listeria monocytogenes C }\end{array}$ & DAFS & BHI & $37^{\circ} \mathrm{C} \times 24 \mathrm{~h}$ \\
\hline Listeria monocytogenes E & DAFS & BHI & $37^{\circ} \mathrm{C} \times 24 \mathrm{~h}$ \\
\hline Listeria monocytogenes 20,600 DSMZ & DSMZ & BHI & $37^{\circ} \mathrm{C} \times 24 \mathrm{~h}$ \\
\hline Salmonella bongori 13,772 DSMZ & DSMZ & BHI & $37^{\circ} \mathrm{C} \times 24 \mathrm{~h}$ \\
\hline
\end{tabular}

${ }^{1}$ DSMZ, Deutsche SammLung von Mikroorganismen und Zellkulturen, German Collection of Microorganism of Cell Cultures; DAFES, Collection of Microorganisms of Dipartimento di Agraria of the University of Sassari, Section of Food and Environmental Science.

The lyophilized hydrolysates (BSPH, PSPH) and non-hydrolysate (CTRL) were weighed and dissolved in Brain Heart Infusion broth (BHI), giving a final concentration of $100 \mathrm{mg} \mathrm{mL}^{-1}$. The solutions were then filter-sterilized on a $0.22 \mu \mathrm{m}$ filter (Sartorius). Aliquots of $100 \mu \mathrm{L}$ of filtered BSPH, PSPH, CTRL, and BHI without hydrolysates (BHI-WH) as positive control were dispensed on 96-wells microtiter plates and inoculated with $5 \mu \mathrm{L}$ of the bacterial suspension as previous prepared. Four wells for each strain and for each solution (BSPH, PSPH, CTRL and $\mathrm{BHI}-\mathrm{WH}$ ) were set up. The antibacterial assay was performed separately on separate microtiter plates for each sample and for each batch.

As blank samples, $100 \mu \mathrm{L}$ BHI-hydrolysate and BHI-WH solutions before incubation were used. The microtiter plates were then incubated at $37^{\circ} \mathrm{C}$ for $24 \mathrm{~h}$ and growth was measured automatically every $30 \mathrm{~min}$ at OD600 using a SPECTROstar nano microplate spectrophotometer reader (BMG Labtech, Ortenberg, Germany). Each growth curve was fitted by the primary model of Baranyi and Roberts [39] wrapped in DMFit Excel add-in [40], that was utilized also to evaluate the maximum specific growth rate $(\mu)$, the duration of lag phase $(\lambda)$ according to Petretto et al. [38]. The 1000XOD absorbance values were log transformed to calculate the growth parameters with DMFIT add-in. Analysis of variance (ANOVA) was performed separately for each bacterial strain tested, using as factor the four treatments: BSPH, PSPH, CTRL, and BHI-WH to evaluate the influence of the two hydrolysates on the values of maximum specific growth rate ( $\mu$ max) and lag phase $(\lambda)$. When a significant effect was observed $(p<0.05)$, the differences between means were separated using the Tukey-Kramer multiple comparisons test. SPSS software, version 22, was used to conduct the statistical analyses.

\subsection{Gel Permeation Chromatography}

The freeze-dried scotta hydrolysates and control samples were reconstituted in water at $6 \mathrm{mg} \mathrm{mL} \mathrm{m}^{-1}$ and filtered on a $0.2 \mu \mathrm{m}$ filter, then analyzed by Gel Permeation high performance liquid Chromatography (GPC) using an Agilent 1260 HPLC system equipped with a DAD detector. The separation was performed at $25{ }^{\circ} \mathrm{C}$ in isocratic mode with a mobile phase composed of $70: 30 \mathrm{ACN}: \mathrm{H}_{2} \mathrm{O}$ with $0.1 \%$ TFA, flowing continuously at 
$0.5 \mathrm{~mL} \mathrm{~min}^{-1}$ through a Phenomenex Yarra SEC-2000 column $(300 \times 7.8 \mathrm{~mm}$; pore size $3 \mu \mathrm{m})$. Samples were filtered through $0.2 \mu \mathrm{m}$ nylon filter and $20 \mu \mathrm{L}$ were injected. The analytical signal was acquired for $30 \mathrm{~min}$ at $214 \mathrm{~nm}$. A calibration of molecular weights (MW) was obtained by acquiring the retention volume of the following pure standards covering a MW range from 181.19 to 66,500 Da: Tyr, Asp-Glu, Leu-Trp-Met-Arg, bacitracin, aprotinin, $\alpha$-La, $\beta$-Lg, BSA. The obtained linear model was adopted to determine the MW distribution of the hydrolysates. The results were expressed as relative abundance by summing the areas of the peaks detected at different molecular weight (obtained by the calibration curve) ranges ( $1 \mathrm{kDa}, 1-5 \mathrm{kDa}, 5-10 \mathrm{kDa}$ and $>10 \mathrm{kDa})$, as previously reported by [41]. Data were analyzed as described in Section 2.4.

A semi-preparative GPC step was further performed on the above-described samples by injecting $100 \mu \mathrm{L}$ in the same conditions above described. The fraction corresponding to a calculated MW between 5000 and 330 Da was collected for further LC-MS/MS analysis.

\subsection{LC-MS/MS Analysis}

Fractions obtained from nine different semi-preparative GPC runs (three of CTRL, three of BSPH and three of PSPH hydrolysates) were brought to dryness and reconstituted in $0.2 \%$ formic acid. The peptide mixture concentration was estimated by measuring absorbance at $280 \mathrm{~nm}$ with a NanoDrop 2000 spectrophotometer (Thermo Scientific, San Jose, CA, USA), using dilutions of the MassPREP E. coli Digest Standard (Waters, Milford, MA, USA) to generate a calibration curve. Peptide concentration was adjusted to $1 \mu \mathrm{g} \mu \mathrm{L}^{-1}$. Two technical replicates for each sample were performed.

LC-MS/MS analyses were carried out using a Q Exactive mass spectrometer (Thermo Scientific) interfaced with an UltiMate 3000 RSLCnano LC system (Thermo Scientific). After loading, peptide mixtures ( $4 \mu \mathrm{g}$ per run) were concentrated and desalted on a trapping precolumn (Acclaim PepMap C18, $75 \mu \mathrm{m} \times 2 \mathrm{~cm}$ nanoViper, $3 \mu \mathrm{m}, 100 \AA$, Thermo Scientific), using $0.2 \%$ formic acid at a flow rate of $5 \mu \mathrm{L} \mathrm{min}^{-1}$. The peptide separation was performed at $35^{\circ} \mathrm{C}$ using a C18 column (EASY-Spray column, $50 \mathrm{~cm} \times 75 \mu \mathrm{m}$ ID, PepMap C18, $3 \mu \mathrm{m}$, Thermo Scientific), using a linear gradient of $245 \mathrm{~min}$ from $5 \%$ to $37.5 \%$ of eluent B $(0.1 \%$ formic acid in $80 \%$ acetonitrile) in eluent $\mathrm{A}\left(0.1 \%\right.$ formic acid), at a flow rate of $250 \mathrm{~nL} \mathrm{~min}^{-1}$. MS data were acquired using a data-dependent Top 12 method dynamically choosing the most abundant precursor ions from the survey scan, under direct control of the Xcalibur software (version 1.0.2.65 SP2, Thermo Fisher Scientific), where a full-scan spectrum (from 300 to $1700 \mathrm{~m} / \mathrm{z}$ ) was followed by tandem mass spectra (MS/MS). The instrument was operated in positive mode with a spray voltage of $1.8 \mathrm{kV}$ and a capillary temperature of $275^{\circ} \mathrm{C}$. Survey and MS/MS scans were performed in the Orbitrap with resolution of 70,000 and 17,500 at $200 \mathrm{~m} / z$, respectively. The automatic gain control was set to $1,000,000$ ions and the lock mass option was enabled on a protonated polydimethylcyclosiloxane background ion as an internal recalibration for accurate mass measurements. The dynamic exclusion was set to $30 \mathrm{~s}$. Higher Energy Collisional Dissociation (HCD), performed at the far side of the C-trap, was used as fragmentation method by applying a $25 \mathrm{eV}$ value for normalized collision energy. An isolation width of $m / z$ 2.0. Nitrogen was used as the collision gas.

Peptide identification was performed using Proteome Discoverer (version 1.4; Thermo Scientific), with Sequest-HT as the search engine for protein identification, according to the following criteria: Database: custom, obtained by merging Bos Taurus and Ovis aries downloaded from UniprotKB, (release 2019_01); Precursor mass tolerance: 10 ppm; Fragment mass tolerance: 0.02 Da; Dynamic modification: methionine oxidation, Asparagine/Glutamine, Arginine deamidation, Serine/Threonine/Tyrosine phosphorylation), and Percolator for peptide validation (FDR $<1 \%$ based on peptide q-value). Results were filtered in order to keep only Rank 1 peptides, and protein grouping was allowed according to the maximum parsimony principle. Protein abundance was expressed by means of the normalized spectral abundance factor (NSAF). NSAF was calculated to evaluate the relative abundance of each protein and peptide, and "log ratio $(\log R)$ " values $\left(\log _{2}\right.$ NSAF group a/NSAF group $b$ ) were obtained to estimate the fold changes of peptides between 
experimental groups expressed as base 2 on a logarithmic scale [42,43]. In this approach, the spectral counts of each peptide were divided by its length and normalized to the average number of spectral counts in a given analysis. In order to eliminate discontinuity due to $\mathrm{SpC}=0$, a correction factor, set to 0.01 , was used.

Peptides showing log ratio $>1.5$ or $<-1.5$ were considered as differentially abundant between groups. A two-tailed $t$-test was applied, using in house software to evaluate the statistical significance of differences between groups. The differentially abundant peptides were then evaluated using the "profiles of potential biological activity" analysis, available on BIOPEP [44] to find within them any sequence with known DPP-IV inhibitory, antioxidant and antibacterial activity.

\section{Results and Discussion}

\subsection{DPP-IV Inhibitory, Antioxidant Activity and GPC Profile of the Selected Hydrolysates}

The DPP-IV inhibitory and ABTS activity of the obtained hydrolysates and of the control samples are showed in Table 2. The P32/98 positive control showed a $\mathrm{IC}_{50}$ of $1.395 \pm 0.007 \times 10^{-3} \mathrm{mg} \mathrm{mL}^{-1}$. In contrast, the retentate control samples (CTRL) did not show a measurable inhibition. BSPH had a significantly higher DPP-IV inhibitory activity compared to PSPH ( $p=0.0381)$. The obtained DPP-IV inhibitory activity was lower than that previously described for milk and whey hydrolysates obtained from WPC, WPI of different species [45-50]. However, the observed activity was just about one order of magnitude less than that measured on hydrolysates obtained from pure $\beta$-lactoglobulin [41]. In addition, a DPP-IV inhibitory activity on hydrolysates from scotta has never been measured before, leading to the consideration of this matrix as a candidate substrate for the industrial production of DPP-IV inhibitory peptides.

Table 2. DPP-IV and antioxidant activity of hydrolysates, and control ${ }^{1}$.

\begin{tabular}{cccc}
\hline Run & BSPH & PSPH & CTRL \\
\hline DPP-IV IC $_{50}\left(\mathrm{mg} \mathrm{mL}^{-1}\right)$ & $8.5^{\mathrm{b}} \pm 0.2$ & $13^{\mathrm{a}} \pm 1$ & n.d. \\
\hline ABTS IC $_{50}\left(\mathrm{mg} \mathrm{mL}^{-1}\right)$ & $0.79^{\mathrm{b}} \pm 0.03$ & $0.87^{\mathrm{ab}} \pm 0.01$ & $1.06^{\mathrm{a}} \pm 0.18$ \\
\hline
\end{tabular}

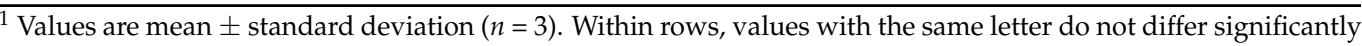
from each other according to LSD test $(p<0.05)$. n.d.: absence of inhibition.

Further, the obtained data confirmed that enzymatic hydrolysis is a suitable way to increase the radical scavenging ability of sheep milk by-products [51]. In fact, BSPH showed a higher antioxidant activity compared to the control. Despite that, the hydrolysates did not differ regarding this property. A similar pattern was found by Monari et al. [15] for bovine scotta hydrolysates, which showed that the antioxidant activity of hydrolysates obtained using bromelain and pancreatin enzymes, did not differ significantly, even using different E:S ratios, both in unconcentrated bovine scotta and retentates.

Figure 1 shows the peptide distribution in terms of relative abundance according to the molecular weight obtained by gel permeation chromatography (GPC), and the comparison among BSPH, PSPH and CTRL.

As expected, most of BSPH and PSPH components were low molecular weight peptides $(<1 \mathrm{kDa})$, whilst the high and medium molecular weight peptides $(>10 \mathrm{kDa}, 5-10 \mathrm{kDa}$, and $1-5 \mathrm{kDa}$ ) were more abundant in the control samples, which conversely showed a very low contribution of components with $\mathrm{MW}<1 \mathrm{kDa}(2.82 \pm 0.21 \%)$. The amount of the 1-5 kDa fraction, even lower than the control, was significantly higher in $\mathrm{BSPH}(31 \pm 0.9 \%)$ than in PSPH $(23.56 \pm 0.02 \%)$. Conversely, pancreatin in our system was more effective in producing peptides with low MW (74 $\pm 1 \%$ ), compared to bromelain $(66 \pm 1 \%)$. Since pancreatin contains a mixture of proteases including chymotrypsin, trypsin and elastase [52], we suppose that in our system it exerted a more generalized proteolytic behavior than bromelain, which conversely has been reported to be less effective in producing free amino acids [15]. The specificity of bromelain may be responsible of the higher DPP-IV inhibitory activity measured in our hydrolysates. 


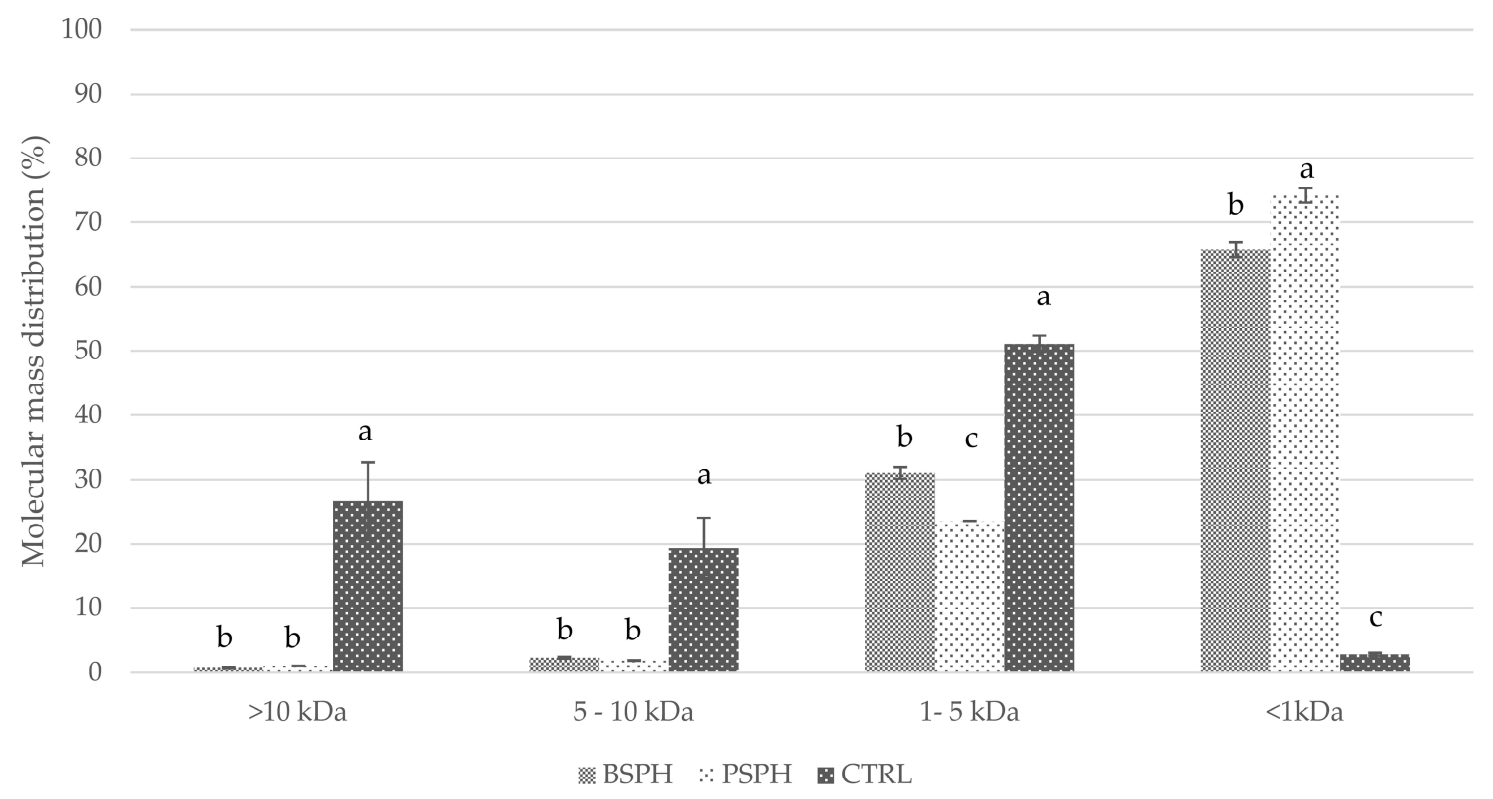

Figure 1. Distribution of the relative abundance (\%) according to molecular weight obtained by gel permeation chromatography (GPC), and the comparison among BSPH, PSPH and CTRL. Values $(n=3)$ with the same letter do not differ significantly from each other according to LSD test $(p<0.05)$.

\subsection{Antibacterial Activities of Hydrolysates}

The enzymatic hydrolysates obtained from ovine scotta tested did not show a complete inhibitory or bactericidal effect on the target microorganisms at the concentration tested $\left(100 \mathrm{mg} \mathrm{mL}^{-1}\right)$. However, the hydrolysates showed a variable but slightly inhibitory effect depending on the species or strain of bacteria tested. In particular, PSPH decreased significantly $(p<0.001)$, the maximum specific growth rate ( $\mu$ max) respect to control being half the values in all bacteria tested except for Salmonella bongori 13,772 DSMZ strain, where the difference of its growth rate respect to control was not significant (see Figure 2A-F). The influence of BSPH was strain-dependent, decreasing significantly the $\mu$ max of Listeria monocytogenes B, Listeria monocytogenes D and Staphylococcus aureus 20,231 DSMZ, whereas the BSPH did not influence the $\mu$ max of L. monocytogenes 20,600 DSMZ, L. monocytogenes B and Salmonella bongori 13,772 DSMZ. An intriguing result was obtained with the CTRL, that decreased the $\mu$ max of Listeria monocytogenes $\mathrm{B}$, L. monocytogenes $\mathrm{C}$ and L. monocytogenes E. All three strains were isolated from ovine ricotta cheese. Regarding the effect of scotta hydrolysates tested, no effect was observed on the lag time $(\lambda)$ of L. monocytogenes $C$, L. monocytogenes E, S. aureus 20,231 DSMZ and S. bongori 13,772 DSMZ. An opposite effect of PSPH on lag time with respect to $\mu$ max was observed on L. monocytogenes 20,600 DSMZ $(\lambda: 3.96 \mathrm{~h})$ and L. monocytogenes B $(\lambda: 1.42 \mathrm{~h})$ strains, with a lag time for each bacterial strains that did not differ significantly from the control $(3.83 \mathrm{~h}$ and $3.39 \mathrm{~h}$ for L. monocytogenes 20,600 DSMZ and $L$. monocytogenes $\mathrm{B}$ control respectively), but was significantly different from the other two treatments (BSPH and CTRL). Overall, all treatments reduced the bacterial density, confirming that scotta hydrolysates negatively influenced the growth of the bacteria tested. Contrasting with our results, Lestari et al. [36] revealed a strong antimicrobial activity of goat milk protein hydrolysate by using bromelain as a hydrolyzing agent. Indeed, the minimum inhibitory concentrations of these hydrolysates against $S$. aureus and Escherichia coli were below $100 \mathrm{ppm}$. Bovine $\beta$-LG and $\alpha$-LA were previously treated with pancreatin, and the resulting hydrolysates were shown to possess antimicrobial activity [53]. 

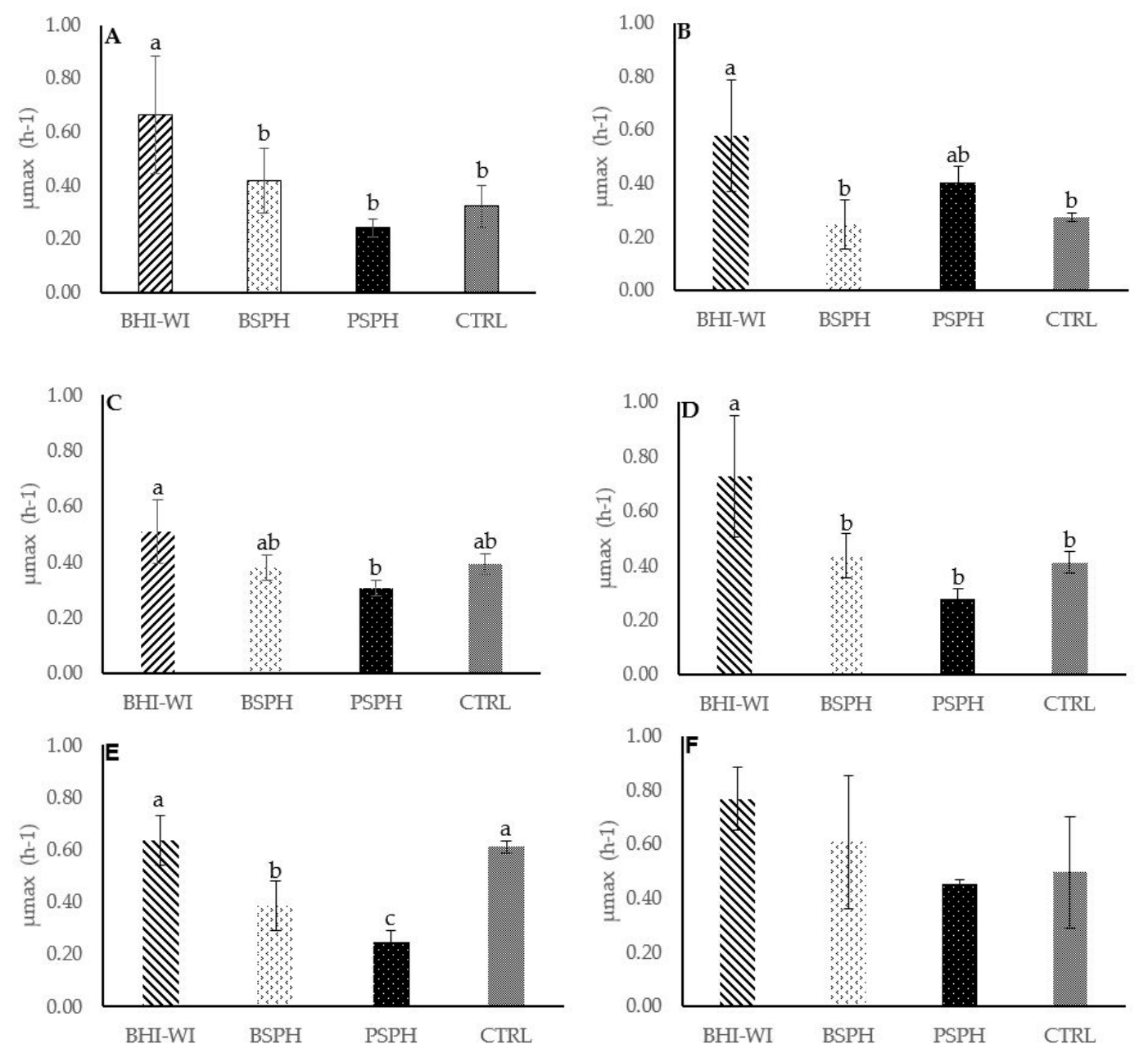

Figure 2. Effect of the different scotta-hydrolysates at concentration of $100 \mathrm{mg} \mathrm{mL}^{-1}$ on the maximum growth rate ( $\mu$ max) of bacteria strains target. BHI-WH, Brain Heart infusion broth medium without hydrolysates; BSPH, Bromelain filter sterilized hydrolysate; PSPH, Pancreatin filter sterilized hydrolysate; CTRL, Scotta not hydrolysate filter sterilized). (Panel (A-F): Listeria monocytogenes B (A); L. monocytogenes C (B); L. monocytogenes 20,600 DSMZ (C); L. monocytogenes E (D); Staphylococcus aureus 20,231 DSMZ (E), Salmonella bongori 13,772 DSMZ (F)). Different lowercase letters above the bar indicate statistically significant differences between different treatments $(p<0.001)$.

\subsection{LC-MS/MS Analysis of Scotta Hydrolysates}

The LC-MS/MS analysis of the GPC fraction of the hydrolysates (BSPH, PSPH and CTRL) described in Section 2.8 allowed acquisition of 12,000 spectra from each run. A total of $58 \pm 7$ proteins and $547 \pm 24$ peptides were identified in BSPH, while $75 \pm 6$ proteins and $559 \pm 33$ peptides were identified in PSPH and further $83 \pm 15$ proteins and $1506 \pm 381$ peptides were identified in the CTRL samples (see Supplementary Materials, Sheet S1).

Considering BSPH vs. CTRL, a total of 29 proteins showed significant differences $(p \leq 0.05)$. Twenty-one of them were more abundant in BSPH, while eight were more abundant in CTRL (see Supplementary Materials, Sheet S2). The differential analysis of BSPH vs. CTRL highlighted 751 significant peptides $(p \leq 0.05)$. Of these, 388 were more abundant in BSPH samples, whilst 363 were more abundant in CTRL samples (see Supplementary Materials, Sheet S3).

Considering the available literature, differential peptides in BSPH were investigated to find sequences with reported DPP-IV inhibition, and antioxidant and antibacterial activity. The candidate peptides were further evaluated using the tool "profiles of potential biological activity" analysis, available on BIOPEP [44]. 
This approach highlighted 97 differential peptides containing at least one of the following sequences with known biological activity: LPQNI, VLGP, VLVLDTDYK, IPAVF, IPA, LKPTPEG, YPVEPF, YQEPVLGPVR, YVEEL, LDTDYKK, IDALNENK, KVAGT, AASDISLLDAGSAPLR, and ALK (see Table 3). All these peptides were attributable to $\beta$ lactoglobulin protein (P67976), except for LPQNI, VLGP, YPVEPF, YQEPVLGPVR derived from $\beta$-casein protein (P11839), and the tripeptide IPA originating from k-casein (P02669). In the following text and in the tables the active sequences contained in the identified peptides will be highlighted with bold characters.

The differential peptides within the DPP-IV sequence showed a length ranging from eight to twenty-eight amino acid residues. The shortest peptide was LDTDYKKY from $\beta$-lactoglobulin with an estimated MW of $1044.52 \mathrm{Da}(\log \mathrm{R}=2.38)$, whilst the longest was AIPPKKDQDKTEIPAINTIASAEPTVHS released from k-casein with an estimated MW of 3051.55 Da $(\log R=2.78)$.

Considering PSPH vs. CTRL, a total of 32 proteins showed a significant difference $(p \leq 0.05)$. Twenty-five of them were more abundant in PSPH samples, while seven were more abundant in CTRL samples (see Supplementary Materials, Sheet S4). The peptide differential analysis of PSPH vs. CTRL highlighted 667 significant peptides $(p \leq 0.05)$. Of these, 294 were differential in PSPH, and 373 were more abundant in the CTRL profile (see Supplementary Materials, Sheet S5).

The "profiles of potential biological activity" analysis on BIOPEP revealed 75 differential peptides containing at least one of the sequences previously observed in BSPH (see Table 4). The sequences with DPP-IV inhibitory activity were encrypted in peptides of 9 to 22 amino acid residues. In detail, KIDALNENK and ALKALPMHI appeared the shortest peptides originating from $\beta$-lactoglobulin with an estimated MW of 1044.56 Da $(\log R=2.84)$ and MW of 992.59 Da ( $\log R=2.03)$ respectively. Furthermore, the longer peptide identified was KDQDKTEIPAINTIASAEPTVH deriving from k-casein, with an estimated MW of 2884.55 Da ( $\log \mathrm{R}=5.07)$.

Venn diagrams were used to evaluate the number of differential peptides, more abundant in BSPH vs. CRTL and PSPH vs. CRTL (Figure 3A,B, respectively), with potential biological activities.

A

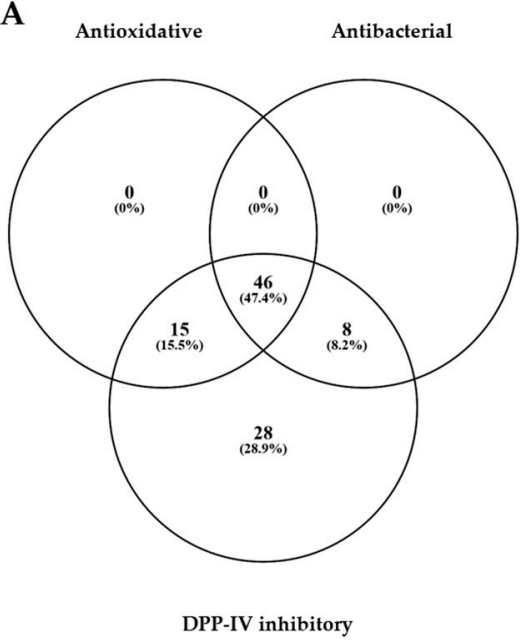

B

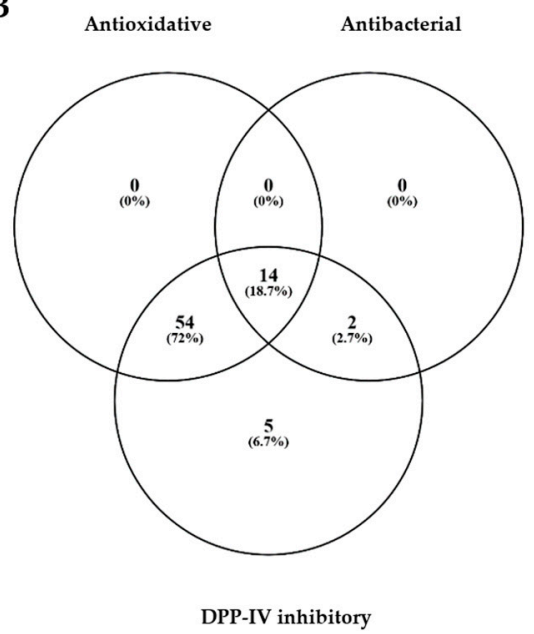

Figure 3. Distribution of the differential peptides more abundant in BSPH vs. CRTL (A) and PSPH vs. CRTL (B), according to their putative biological activities (DPP-IV inhibition, antioxidative and antibacterial properties).

Venn diagrams highlighted that none of the peptides contained sequences with only antibacterial or antioxidant known activity (Figure $3 \mathrm{~A}, \mathrm{~B}$ ). Interestingly, the $72 \%$ of the peptides in PSPH compared to the CTRL, contained sequences associated with antioxidant and DPP-IV inhibitory activity (Figure 3B). Moreover, a 5.6-fold higher number of peptides 
containing sequences with only DPP-IV inhibitory activity was found in BSPH vs. CTRL compared to PSPH vs. CTRL.

Furthermore, the differential analysis of BSPH vs. PSPH showed 82 proteins in total and 29 differentials $(p \leq 0.05)$. Among them, 21 were more abundant in BSPH, while eight were more abundant in PSPH (see Supplementary Materials, Sheet S6). The peptide analysis indicated 1181 peptides, and 752 were significantly differential $(p \leq 0.05)$. Among them, 388 peptides were more abundant in BSPH, while 364 were more abundant in PSPH (see Supplementary Materials, Sheet S7).

A total of 208 differential peptides contained sequences with known DPP-IV inhibitory activity (see Table 5).

Figure 4 groups differential peptides (BSPH vs. PSPH) generated by the same protein and dividing the components according to reported biological activity. Histograms show, for each protein ( $\beta$-casein, $\mathrm{k}$-casein, and $\beta$-lactoglobulin), the peptides more abundant in $\mathrm{BSPH}$ or in PSPH, respectively.

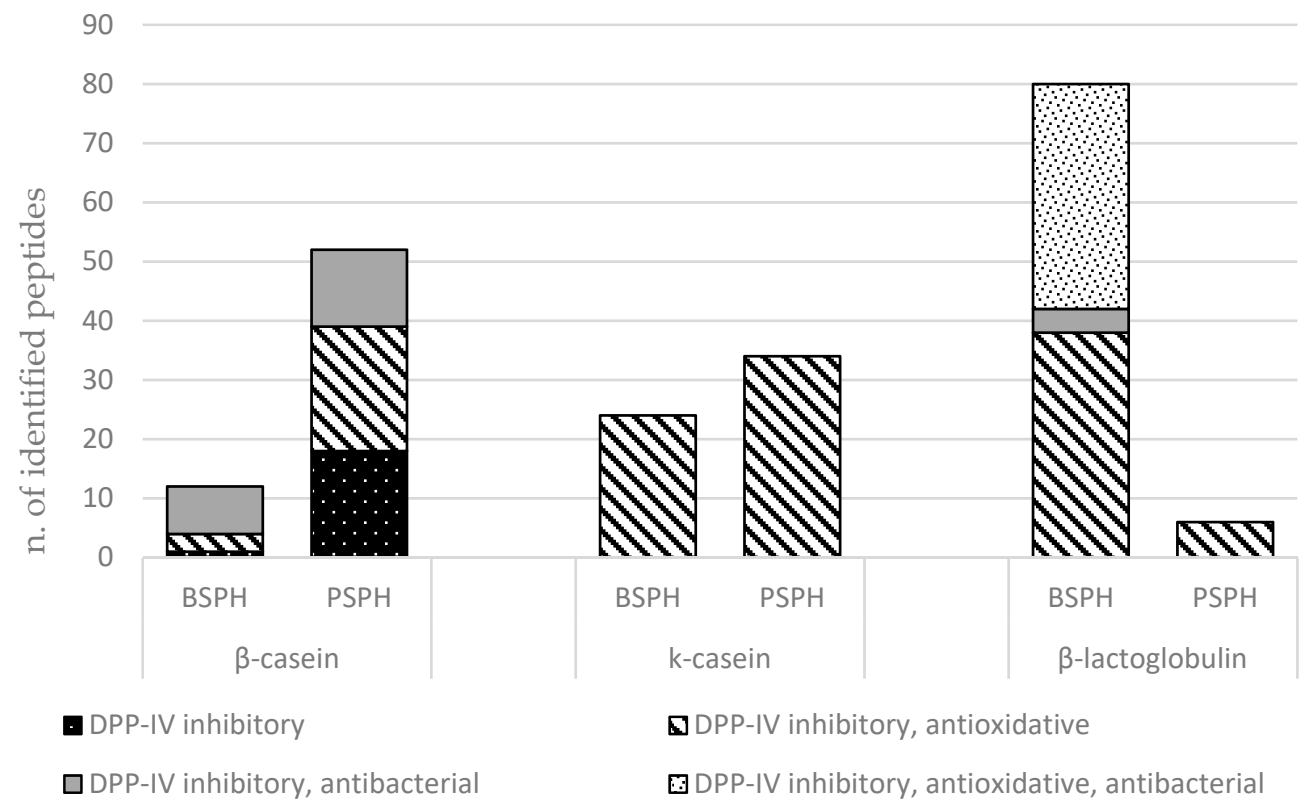

Figure 4. Number of differential peptides (BSPH vs. PSPH) grouped by the proteins and biological activities.

Sixty-four differential peptides were derived from $\beta$-casein, 52 of which were more abundant in PSPH, and 12 were more abundant in BSPH (Figure 4). Fifty-eight differential peptides were originated from k-casein 24, of which were more abundant in BSPH and 34 were more abundant in PSPH.

Interestingly, the number of differential peptides derived from $\beta$-lactoglobulin was differently distributed between BSPH and PSPH. In fact, a total of 86 differential peptides derived from $\beta$-lactoglobulin were identified, 80 of them more abundant in BSPH and six in PSPH. This result could help to interpret the higher DPP-IV inhibitory activity showed in vitro by BSPH compared to PSPH. Moreover, none of the identified peptides derived from $\alpha$-lactalbumin. Power et al. [50], found in silico a three-fold higher content of peptide sequences with potential DPP-IV inhibitory activity in $\beta$-lactoglobulin compared to $\alpha$ lactalbumin. Furthermore, Tulipano et al. [54] found by in silico analysis that bovine $\beta$-lactoglobulin was a better source of DPP-IV inhibitory peptides compared with $\alpha$ lactalbumin after treatment with digestive proteases. 
Table 3. Analysis of differential peptides of BSPH vs. CTRL ( $\log R \geq 1.5$ and $\log R \leq-1.5)$.

\begin{tabular}{|c|c|c|c|c|}
\hline ID Protein & Identified Peptide & $\begin{array}{c}\log _{2} \\
\text { BSPH vs. CTRL }\end{array}$ & Activity & Reference \\
\hline \multirow{2}{*}{$\beta$-casein } & GPIPNSLPQNILPLT T9-94 & 3.82 & Antioxidative; & \multirow{2}{*}[55,56]{} \\
\hline & GPIPNSLPQNILPLTQ ${ }^{79-95}$ & 3.78 & DPP-IV inhibitory; & \\
\hline$\beta$-casein & YQEPVLGPVR $206-215$ & 2.1 & $\begin{array}{c}\text { Antioxidative; } \\
\text { DPP-IV inhibitory; }\end{array}$ & [57-65] \\
\hline \multirow{13}{*}{$\beta$-lactoglobulin } & VLVLDTDYK $^{110-118}$ & 2.21 & \multirow{13}{*}{$\begin{array}{c}\text { Antioxidative; } \\
\text { Antibacterial; } \\
\text { DPP-IV inhibitory; }\end{array}$} & \multirow{13}{*}{ [66-73] } \\
\hline & VLVLDTDYKK $^{110-119}$ & 3.05 & & \\
\hline & VLVLDTDYKKYY110-120 & 3.42 & & \\
\hline & VLVLDTDYKKYL ${ }^{110-121}$ & 2.72 & & \\
\hline & VLVLDTDYKKYLL ${ }^{110-122}$ & 2.17 & & \\
\hline & KVLVLDTDYKKY'109-120 & 1.67 & & \\
\hline & ENKVLVLDTDYKK ${ }^{107-119}$ & 2.48 & & \\
\hline & ENKVLVLDTDYKKY ${ }^{107-120}$ & 3.45 & & \\
\hline & ENKVLVLDTDYKKYL ${ }^{107-121}$ & 2.18 & & \\
\hline & DALENKVLVLDTDYKK ${ }^{104-119}$ & 1.90 & & \\
\hline & DALENKVLVLDTDYKKY ${ }^{104-120}$ & 2.43 & & \\
\hline & IDALENKVLVLDTDYKK ${ }^{103-119}$ & 2.33 & & \\
\hline & IDALENKVLVLDTDYKKY $Y^{103-120}$ & 3.05 & & \\
\hline \multirow{3}{*}{$\beta$-lactoglobulin } & IPAVFKIDALNENK ${ }^{96-109}$ & 2.43 & Antioxidative; & \multirow{3}{*}[26,67,68,71,74-76]{} \\
\hline & TKIPAVFKIDALNENK ${ }^{94-109}$ & 1.83 & Antibacterial; & \\
\hline & & & & \\
\hline \multirow{24}{*}{ k-casein } & DQDKTEIPAINTIASAEPTVHS ${ }^{134-155}$ & 5.40 & \multirow{24}{*}{ DPP-IV inhibitory; } & \multirow{24}{*}[26,41,75,77,78]{} \\
\hline & AIPPKKDQDKTEIPAINT ${ }^{128-145}$ & 5.39 & & \\
\hline & EIPAINTIASAEPTVHS ${ }^{139-155}$ & 5.28 & & \\
\hline & IPPKKDQDKTEIPAINTIA ${ }^{129-147}$ & 4.69 & & \\
\hline & IPAINTIASAEPTVHS ${ }^{140-155}$ & 4.62 & & \\
\hline & IPPKKDQDKTEIPAIN ${ }^{129-144}$ & 4.49 & & \\
\hline & IPPKKDQDKTEIPAINT ${ }^{129-145}$ & 4.46 & & \\
\hline & PPKKDQDKTEIPAINTIAS ${ }^{130-148}$ & 3.96 & & \\
\hline & AIPPKKDQDKTEIPAINTIA ${ }^{128-147}$ & 3.90 & & \\
\hline & AIPPKKDQDKTEIPAIN ${ }^{128-144}$ & 3.84 & & \\
\hline & KDQDKTEIPAINT ${ }^{132-145}$ & 3.59 & & \\
\hline & KDQ̄DKTEIPAINTIA ${ }^{132-147}$ & 3.46 & & \\
\hline & EIPAINTIASAEPTVH ${ }^{139-154}$ & 3.37 & & \\
\hline & DQDKTEIPAINTIAS ${ }^{134-148}$ & 3.29 & & \\
\hline & IPAINTIASAEPTVH ${ }^{140-154}$ & 3.22 & & \\
\hline & DQDKTEIPAINTIASAEPTVH ${ }^{144-154}$ & 3.14 & & \\
\hline & TEIPAINTIASAEPTVHS ${ }^{138-155}$ & 2.99 & & \\
\hline & PPKKDQDKTEIPAInTIASAEP130-151 & 2.87 & & \\
\hline & AIPPKKDQDKTEIPAINTIASAEPTVHS ${ }^{128-155}$ & 2.78 & & \\
\hline & DQDKTEIPAINTI ${ }^{134-146}$ & 2.59 & & \\
\hline & KDQDKTEIPAINTIASAEPTVHS ${ }^{133-155}$ & 2.33 & & \\
\hline & PPKKDQDKTEIPAINTIA ${ }^{130-147}$ & 2.31 & & \\
\hline & KDQDKTEIPAIN ${ }^{133-144}$ & 1.84 & & \\
\hline & DQDKTEIPAINTIA $^{134-147}$ & 1.50 & & \\
\hline \multirow{6}{*}{$\beta$-lactoglobulin } & VYVEELKPTPEG ${ }^{59-70}$ & 2.10 & \multirow{6}{*}{$\begin{array}{c}\text { Antioxidative; } \\
\text { DPP-IV inhibitory; }\end{array}$} & \multirow{6}{*}{ [31] } \\
\hline & ELKPTPEGNLEILLQ ${ }^{63-77}$ & 2.03 & & \\
\hline & EELKPTPEGNL ${ }^{62-72}$ & 1.99 & & \\
\hline & VYVEELKPTPEGNL ${ }^{59-72}$ & 1.74 & & \\
\hline & VYVEELKPTPEGNLE ${ }^{59-73}$ & 1.69 & & \\
\hline & EELKPTPEGNLEILL ${ }^{62-76}$ & 1.67 & & \\
\hline
\end{tabular}


Table 3. Cont

\begin{tabular}{|c|c|c|c|c|}
\hline ID Protein & Identified Peptide & $\begin{array}{c}\log _{2} \\
\text { BSPH vs. CTRL }\end{array}$ & Activity & Reference \\
\hline$\beta$-casein & $\begin{array}{l}\text { EMPFPKYPVEPFT }^{123-135} \\
\text { MPFPKYPVEPFTE }^{124-136} \\
\text { EMPFPKYPVEPFTE }^{123-136} \\
\text { MPFPKYPVEPFT }^{124-135} \\
\text { MPFPKYPVEPFTES }^{124-137} \\
\text { EMPFPKYPVEPFTES }^{123-137} \\
\text { MPFPKYPVEPF }^{124-134} \\
\text { EMPFPKYPVEPF }^{123-134}\end{array}$ & $\begin{array}{l}4.23 \\
4.01 \\
3.96 \\
3.90 \\
3.39 \\
3.15 \\
1.93 \\
1.90\end{array}$ & $\begin{array}{c}\text { Antibacterial; } \\
\text { DPP-IV inhibitory; }\end{array}$ & {$[27,65,79-81]$} \\
\hline$\beta$-casein & YQEPVLGPVR $^{208-212}$ & 2.10 & $\begin{array}{l}\text { DPP-IV inhibitory; } \\
\text { Antioxidative; }\end{array}$ & {$[58,60,62,64]$} \\
\hline$\beta$-lactoglobulin & $\begin{array}{l}\text { VYVEELKPTPEG }{ }^{59-70} \\
\text { VYVEELKPTPEGNL } \\
\text { VY-72 } \\
\text { VYVELKPTPEGNLE }\end{array}$ & $\begin{array}{l}2.10 \\
1.74 \\
1.69\end{array}$ & $\begin{array}{l}\text { DPP-IV inhibitory; } \\
\text { Antioxidative; } \\
\text { Antibacterial }\end{array}$ & {$[24,82,83]$} \\
\hline$\beta$-lactoglobulin & 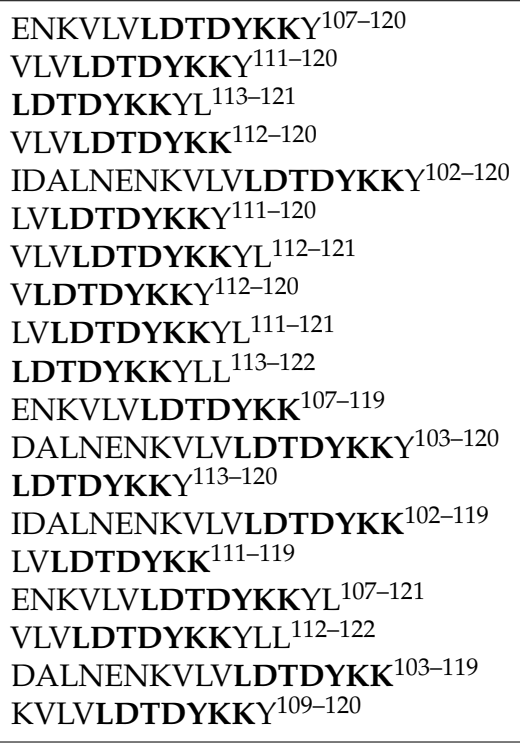 & $\begin{array}{l}3.45 \\
3.42 \\
3.18 \\
3.05 \\
3.05 \\
2.94 \\
2.72 \\
2.62 \\
2.52 \\
2.48 \\
2.48 \\
2.43 \\
2.38 \\
2.33 \\
2.23 \\
2.18 \\
2.17 \\
1.90 \\
1.67 \\
\end{array}$ & $\begin{array}{l}\text { Antioxidative; } \\
\text { Antibacterial; } \\
\text { DPP-IV inhibitory; }\end{array}$ & {$[44,84]$} \\
\hline$\beta$-lactoglobulin & $\begin{array}{l}\text { IPAVFKIDALNENK }^{96-109} \\
\text { IDALNENKVLVLDTDYKKY }^{102-120} \\
\text { IDALNENKVL }^{102-111} \\
\text { TKIPAVFKIDALNENK } \\
\text { IDALNENKN }^{94} \\
\text { KIPAVFKIDALNENKK }^{95-109} \\
\text { KIDALNENK }^{101-109} \\
\text { VFKIDALNENK }^{99-109} \\
\text { IDALNENKV }^{102-110}\end{array}$ & $\begin{array}{l}3.09 \\
3.05 \\
2.60 \\
2.46 \\
2.33 \\
2.30 \\
2.21 \\
1.99 \\
1.96\end{array}$ & $\begin{array}{l}\text { DPP-IV inhibitory; } \\
\text { Antioxidative; } \\
\text { Antibacterial; }\end{array}$ & {$[44,85]$} \\
\hline$\beta$-lactoglobulin & LDIQKVAGTWHS ${ }^{27-39}$ & 1.92 & $\begin{array}{l}\text { DPP-IV inhibitory; } \\
\text { Antioxidative; }\end{array}$ & [86] \\
\hline$\beta$-lactoglobulin & $\begin{array}{l}\text { AASDISLLDAQSAPLR } \\
\text { LAMAA-59 }^{43} \\
\text { MAASDISLLDAQSAPLR }^{42-59} \\
\text { AASDISLLDAQSAPLRV }^{43-59}\end{array}$ & $\begin{array}{l}2.57 \\
2.37 \\
1.88 \\
1.53\end{array}$ & DPP-IV inhibitory; & {$[68,71]$} \\
\hline$\beta$-lactoglobulin & 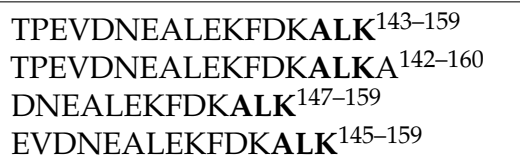 & $\begin{array}{l}4.03 \\
2.92 \\
2.38 \\
2.01\end{array}$ & $\begin{array}{l}\text { DPP-IV inhibitory; } \\
\text { Antioxidative; }\end{array}$ & [76] \\
\hline
\end{tabular}


Table 4. Analysis of differential peptides of PSPH vs. CTRL $(\log R \geq 1.5$ and $\log R \leq-1.5)$.

\begin{tabular}{|c|c|c|c|c|}
\hline ID Protein & Identified Peptide & $\begin{array}{c}\log _{2} \\
\text { PSPH vs. CTRL }\end{array}$ & Activity & Reference \\
\hline$\beta$-casein & TGPIPNSLPQNILPL ${ }^{78-92}$ & 2.53 & $\begin{array}{c}\text { DPP-IV inhibitory; } \\
\text { Antioxidative; }\end{array}$ & {$[55,56]$} \\
\hline$\beta$-casein & $\begin{array}{l}\text { QEPVLGPVRGPFPI }{ }^{207-220} \\
\text { QEPVLGPVRGPFP }^{207-219} \\
\text { YQEPVLGPVRGPFPI }^{206-220} \\
\text { LYQEPVLGPVRGPFPI }^{205-220} \\
\text { EPVLGPVRGPFPI }^{208-220}\end{array}$ & $\begin{array}{l}4.06 \\
3.44 \\
2.45 \\
1.91 \\
1.85 \\
\end{array}$ & DPP-IV inhibitory; & [57-65] \\
\hline$\beta$-lactoglobulin & 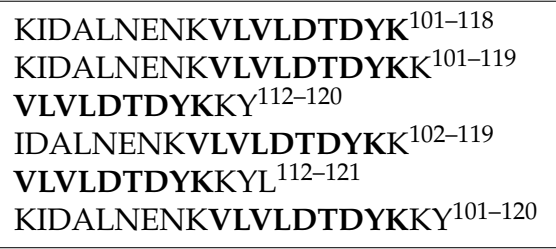 & $\begin{array}{l}2.83 \\
2.50 \\
2.20 \\
2.04 \\
1.93 \\
1.57\end{array}$ & $\begin{array}{c}\text { DPP-IV inhibitory; } \\
\text { Antioxidative; } \\
\text { Antibacterial; }\end{array}$ & {$[66-73]$} \\
\hline$\beta$-lactoglobulin & IPAVFKIDALNENK ${ }^{96-109}$ & 1.76 & $\begin{array}{c}\text { DPP-IV inhibitory; } \\
\text { Antioxidative; } \\
\text { Antibacterial; }\end{array}$ & {$[26,67,68,71,74-76]$} \\
\hline k-casein & $\begin{array}{l}\text { KDQDKTEIPAINTIASAEPT } \\
\text { KDQDKTEIPAINT }^{133-143} \\
\text { TEIPAINTIASAEPTVH }^{138-154} \\
\text { KDQDKTEIPAINTIA }^{133-146} \\
\text { KDQDKTEIPAINTIASAEPTVH }^{133-154} \\
\text { DQDKTEIPAINTIASAEPT }^{134-152} \\
\text { DQDKTEIPAINTIASAEPTVH }^{134-154} \\
\text { KDQDKTEIPAIN }^{133-143} \\
\text { KDQDKTEIPAINTIAS }^{133-147} \\
\text { KDQDKTEIPAI }^{133-142} \\
\text { EIPAINTIASAEPTVH }^{139-154} \\
\text { KDQDKTEIPAINTI }^{133-145} \\
\text { DQDKTEIPAINTIAS }^{134-147} \\
\text { DQDKTEIPAINTIA }^{134-146} \\
\text { DQDKTEIPAINTI }^{134-145} \\
\text { MAIPPKKDQDKTEIPA }^{127-142} \\
\text { AIPPKKDQDKTEIPAIN } \\
\text { AIPPKKD-144 }^{128} \\
\text { PPKKDQDTEIPAINTIA }^{128-147} \\
\text { MAIPPKKDQDKTEIPAINTIA }^{127-147} \\
\text { AIPPKKDQDKTEIPA }^{128-142}\end{array}$ & $\begin{array}{l}5.99 \\
5.85 \\
5.17 \\
5.13 \\
5.07 \\
5.05 \\
5.04 \\
4.39 \\
3.96 \\
3.92 \\
3.91 \\
3.90 \\
3.65 \\
3.42 \\
3.32 \\
2.95 \\
2.70 \\
2.64 \\
2.32 \\
2.09 \\
1.68\end{array}$ & $\begin{array}{l}\text { DPP-IV inhibitory; } \\
\text { Antioxidative; }\end{array}$ & {$[26,41,75,77,78]$} \\
\hline$\beta$-lactoglobulin & $\begin{array}{l}\text { VEELKPTPEGNLE }^{61-73} \\
\text { VEELKPTPEGNLEI }^{61-74} \\
\text { VEELKPTPEGNLEILLQK }^{61-78} \\
\text { VEELKPTPEGNLEIL }^{61-76} \\
\text { YVEELKPTPEGNLE }^{60-73} \\
\text { VEELKPTPEGDLE }^{59-71} \\
\text { VYVEELKPTPEGN }^{59-71} \\
\text { VYVEELKPTPEGNLE }^{59-73} \\
\text { YVEELKPTPEGN } \\
\text { Y0-70 } \\
\text { YVEELKPTPEGNLEI I9-74 }^{59} \text { YVEELKPTPEGNLEILLQK }^{59-78} \\
\text { YVEELKPTPEGNLEIL } \\
\text { VY-75 } \\
\text { VEVELLKPTPEGNLEILLQK } \\
\text { VE-78 } \\
\text { RVYVEELKPTPEGNLEILLQK } \\
\text { VY-78 } \\
\text { VYVELKPTPEGNL } \\
58-72\end{array}$ & $\begin{array}{l}3.51 \\
3.35 \\
2.97 \\
2.96 \\
2.89 \\
2.64 \\
2.64 \\
2.63 \\
2.61 \\
2.45 \\
2.28 \\
2.27 \\
2.02 \\
1.93 \\
1.87 \\
1.76\end{array}$ & $\begin{array}{c}\text { DPP-IV inhibitory; } \\
\text { Antioxidative; }\end{array}$ & [31] \\
\hline$\beta$-casein & EMPFPКYPVEPF ${ }^{129-134}$ & 1.93 & $\begin{array}{l}\text { DPP-IV inhibitory; } \\
\text { Antibacterial; }\end{array}$ & {$[27,65,79-81]$} \\
\hline
\end{tabular}


Table 4. Cont.

\begin{tabular}{|c|c|c|c|c|}
\hline ID Protein & Identified Peptide & $\begin{array}{c}\log _{2} \\
\text { PSPH vs. CTRL }\end{array}$ & Activity & Reference \\
\hline$\beta$-casein & $\begin{array}{l}\text { YQEPVLGPVRGPFPI } \\
\text { LYQEPVLGPVIRGPFPI }^{206-215}\end{array}$ & $\begin{array}{l}2.45 \\
1.91\end{array}$ & $\begin{array}{l}\text { DPP-IV inhibitory; } \\
\text { Antioxidative; }\end{array}$ & {$[58,60,62,64]$} \\
\hline$\beta$-lactoglobulin & $\begin{array}{l}\text { VYVEELKPTPEGN } \\
\text { VY-71 } \\
\text { VYVEELKPTPEGNLE }^{59-73} \\
\text { VYVEELKPTPEGNLEILLQK } \\
\text { RVY-78 } \\
\text { VYVEELKPTPEGNLEILLQK } \\
\text { VY-78 }\end{array}$ & $\begin{array}{l}2.64 \\
2.63 \\
2.02 \\
1.87 \\
1.76\end{array}$ & $\begin{array}{l}\text { DPP-IV inhibitory; } \\
\text { Antioxidative; }\end{array}$ & {$[24,82,83]$} \\
\hline$\beta$-lactoglobulin & $\begin{array}{l}\text { KIDALNENKVLVLDTDYKK } \\
\text { VLVLDTDY119 } \\
\text { VLDTDYKKYLY } \\
\text { I112-121 } \\
\text { IDALNENKVLVLDTDYKK } \\
\text { VLVLD-119 } \\
\text { KIDALNENKVLYYLLLI12-121 }\end{array}$ & $\begin{array}{l}2.50 \\
2.20 \\
2.12 \\
2.04 \\
1.93 \\
1.57\end{array}$ & $\begin{array}{c}\text { DPP-IV inhibitory; } \\
\text { Antibacterial; } \\
\text { Antioxidative; }\end{array}$ & {$[44,84]$} \\
\hline$\beta$-lactoglobulin & $\begin{array}{l}\text { KIDALNENKV }^{101-110} \\
\text { KIDALNENK }^{101-109} \\
\text { KIDALNENKVLVLDTDYK }^{101-118} \\
\text { KIDALNENKVLVLDTDYKK } \\
\text { IDALNENKVLVLDTDYKK }^{102-119} \\
\text { IPAVFKIDALNENK }^{96-109} \\
\text { KIDALNENKVLVLDTDYKKY }^{100-120}\end{array}$ & $\begin{array}{l}3.39 \\
2.84 \\
2.83 \\
2.50 \\
2.04 \\
1.76 \\
1.57\end{array}$ & $\begin{array}{l}\text { DPP-IV inhibitory; } \\
\text { Antioxidative; }\end{array}$ & {$[44,85]$} \\
\hline$\beta$-lactoglobulin & GLDIQKVAGTWH' ${ }^{27-38}$ & 1.73 & $\begin{array}{l}\text { DPP-IV inhibitory; } \\
\text { Antioxidative; }\end{array}$ & [86] \\
\hline$\beta$-lactoglobulin & $\begin{array}{l}\text { SLAMAASDISLLDAQSAPLRV }^{39-59} \\
\text { SLAMAASDISLLDAQSAPLR }^{39-58}\end{array}$ & $\begin{array}{l}2.56 \\
2.21\end{array}$ & $\begin{array}{l}\text { DPP-IV inhibitory; } \\
\text { Antibacterial; }\end{array}$ & {$[68,71]$} \\
\hline$\beta$-lactoglobulin & ALKALPMHI ${ }^{157-165}$ & 2.03 & $\begin{array}{l}\text { DPP-IV inhibitory; } \\
\text { Antioxidative; }\end{array}$ & [76] \\
\hline
\end{tabular}

The active sequences contained in longer peptides are highlighted with bold characters.

Table 5. Analysis of differential peptides of BSPH vs. PSPH ( $\log R \geq 1.5$ and $\log R \leq-1.5)$.

\begin{tabular}{|c|c|c|c|}
\hline ID Protein & Identified Peptide & $\begin{array}{c}\log _{2} \\
\text { BSPH vs. PSPH }\end{array}$ & Activity \\
\hline$\beta$-casein & 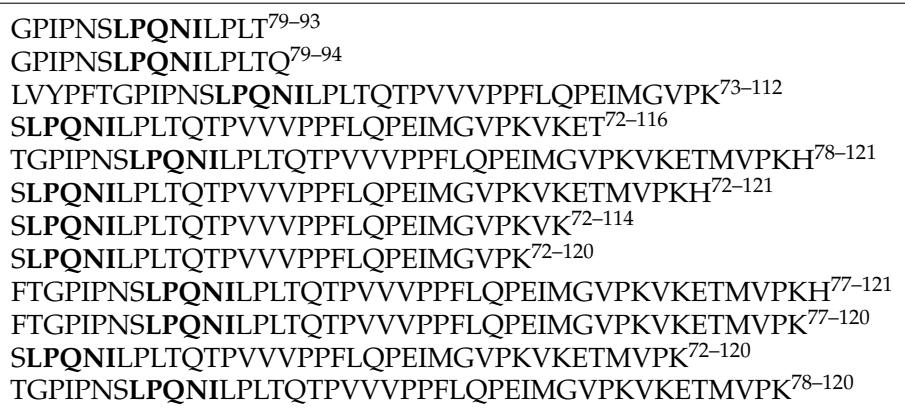 & $\begin{array}{l}3.82 \\
3.78 \\
-1.54 \\
-1.62 \\
-1.69 \\
-1.91 \\
-1.92 \\
-1.98 \\
-2.44 \\
-3.44 \\
-3.47 \\
-3.53\end{array}$ & $\begin{array}{c}\text { DPP-IV inhibitory; } \\
\text { Antioxidative; }\end{array}$ \\
\hline$\beta$-casein & 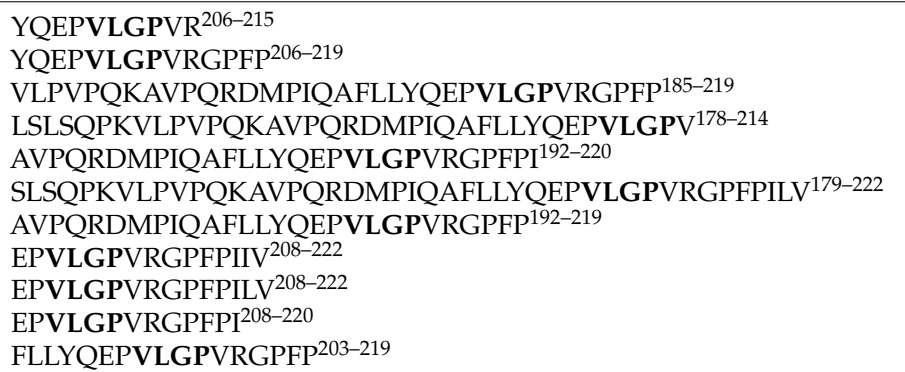 & $\begin{array}{l}2.10 \\
-1.61 \\
-1.64 \\
-1.71 \\
-1.75 \\
-1.77 \\
-1.80 \\
-1.89 \\
-1.89 \\
-2.01 \\
-2.10\end{array}$ & DPP-IV inhibitory; \\
\hline
\end{tabular}


Table 5. Cont.

\begin{tabular}{|c|c|c|c|}
\hline ID Protein & Identified Peptide & $\begin{array}{c}\log _{2} \\
\text { BSPH vs. PSPH }\end{array}$ & Activity \\
\hline & VLPVPQKAVPQRDMPIQAFLLYQEPVLGPVRGPFPILV ${ }^{185-222}$ & -2.14 & \\
\hline & VLPVPQKAVPQRDMPIQ̄AFLLYQ̄EPVLGPVRGPFPI ${ }^{185-220}$ & -2.24 & \\
\hline & YQEPVLGPVRGPFPIIV ${ }^{206-222}$ & -2.31 & \\
\hline & YQEPVLGPVRGPFPILV $206-222$ & -2.31 & \\
\hline & VLPVPQKAVPQRDMPIQAFLLYQEPVLGPVRGPFPIL ${ }^{185-221}$ & -2.33 & \\
\hline & EPVLGPVRGPFPII ${ }^{208-221}$ & -2.59 & \\
\hline & EPVLGPVRGPFPIL ${ }^{208-221}$ & -2.59 & \\
\hline & EPVLGPVRGPFP $208-219$ & -2.98 & \\
\hline \multirow{13}{*}{$\beta$-lactoglobulin } & ENKVLVLDTDYKKY107-118 & 3.45 & \multirow{13}{*}{$\begin{array}{l}\text { DPP-IV inhibitory; } \\
\text { Antioxidative; } \\
\text { Antibacterial; }\end{array}$} \\
\hline & VLVLDTDYKKY $Y^{110-120}$ & 3.42 & \\
\hline & VLVLDTDYKK $^{112-119}$ & 3.05 & \\
\hline & IDALNENKVLVLDTDYKKY Y02-120 & 3.05 & \\
\hline & VLVLDTDYKKYL $^{112-120}$ & 2.72 & \\
\hline & ENKVLVLDTDYKK ${ }^{107-119}$ & 2.48 & \\
\hline & DALNENKVLVLDTDYKKY $Y^{103-120}$ & 2.43 & \\
\hline & IDALNENKVLVLDTDYKK ${ }^{102-119}$ & 2.33 & \\
\hline & VLVLDTDYK $^{112-118}$ & 2.21 & \\
\hline & ENKVLVLDTDYKKYL ${ }^{107-121}$ & 2.18 & \\
\hline & VLVLDTDYKKYLL ${ }^{112-120}$ & 2.17 & \\
\hline & DALNENKVLVLDTDYKK ${ }^{103-119}$ & 1.90 & \\
\hline & KVLVLDTDYKKY $Y^{109-120}$ & 1.67 & \\
\hline \multirow{3}{*}{$\beta$-lactoglobulin } & IPAVFKIDALNENK ${ }^{106-109}$ & 3.09 & \multirow{3}{*}{$\begin{array}{c}\text { DPP-IV inhibitory; } \\
\text { Antioxidative; } \\
\text { Antibacterial; }\end{array}$} \\
\hline & TKIPAVFKIDALNENK ${ }^{104-109}$ & 2.46 & \\
\hline & KIPAVFKIDALNENK ${ }^{105-109}$ & 2.30 & \\
\hline \multirow{40}{*}{ k-casein } & DQDKTEIPAINTIASAEPTVHS ${ }^{134-155}$ & 5.40 & \multirow{40}{*}{$\begin{array}{l}\text { DPP-IV inhibitory; } \\
\text { Antioxidative; }\end{array}$} \\
\hline & AIPPKKDQDKTEIPAINT ${ }^{128-145}$ & 5.39 & \\
\hline & EIPAINTIASAEPTVHS ${ }^{139-155}$ & 5.28 & \\
\hline & IPPKKDQDKTEIPAINTIA ${ }^{129-147}$ & 4.69 & \\
\hline & IPAINTIASAEPTVHS ${ }^{140-155}$ & 4.62 & \\
\hline & IPPKKDQDKTEIPAIN $^{129-144}$ & 4.49 & \\
\hline & IPPKKDQDKTEIPAINT $^{129-145}$ & 4.46 & \\
\hline & PPKKDQDKTEIPAINTIAS ${ }^{130-148}$ & 3.96 & \\
\hline & AIPPKKDQDKTEIPAINTIA ${ }^{128-147}$ & 3.90 & \\
\hline & AIPPKKDQDKTEIPAIN ${ }^{128-144}$ & 3.84 & \\
\hline & KDQDKTEIPAINT ${ }^{133-145}$ & 3.59 & \\
\hline & KDQDKTEIPAINTIA ${ }^{133-147}$ & 3.46 & \\
\hline & EIPAIINTIASAEPTVH ${ }^{139-154}$ & 3.37 & \\
\hline & DQDKTEIPAINTIAS ${ }^{134-148}$ & 3.29 & \\
\hline & IPAINTIASAEPTVH ${ }^{140-154}$ & 3.22 & \\
\hline & DQDKTEIPAINTIASAEPTVH ${ }^{134-154}$ & 3.14 & \\
\hline & TEIPAINTIASAEPTVHS ${ }^{138-155}$ & 2.99 & \\
\hline & PPKKDQDKTEIPAINTIASAEP ${ }^{130-151}$ & 2.87 & \\
\hline & AIPPKKDQDKTEIPAINTIASAEPTVHS $128-155$ & 2.78 & \\
\hline & DQDKTEIPAINTI ${ }^{134-146}$ & 2.59 & \\
\hline & KDQDKTEIPAINTIASAEPTVHS ${ }^{133-155}$ & 2.33 & \\
\hline & PPKKDQDKTEIPAINTIA ${ }^{130-147}$ & 2.31 & \\
\hline & KDQDKTEIPAIN ${ }^{133-144}$ & 1.84 & \\
\hline & DQDKTEIPAINTIA $^{134-147}$ & 1.50 & \\
\hline & FMAIPPKKDQDKTEIPAINTIASAEPTVH ${ }^{126-154}$ & -1.53 & \\
\hline & MAIPPKKDQDKTEIPAINTIASAEPTVHSTPTTEAVVNAVDNPP $127-169$ & -1.71 & \\
\hline & KTEIPAINTIASAEPTVH ${ }^{137-154}$ & -1.94 & \\
\hline & MAIPPKKDQDKTEIPAINTIASAEPTVHSTPTTEAVV ${ }^{127-163}$ & -2.01 & \\
\hline & IPPKKDQDKTEIPAINTIASAEPTVH ${ }^{129-154}$ & -2.18 & \\
\hline & MAIPPKKDQDKTEIPAINTIASAEPTVHSTP ${ }^{127-157}$ & -2.36 & \\
\hline & MAIPPKKDQ̄DKTEIPAINTIASAEPTVHSTPTTEAVVNAV²7-166 & -2.37 & \\
\hline & MAIPPKKDQDKTEIPAINTIASAEPTV ${ }^{127-153}$ & -2.39 & \\
\hline & MAIPPKKDQDKTEIPAINTIASAEP $127-151$ & -2.42 & \\
\hline & MAIPPKKDQDKTEIPAINT ${ }^{127-144}$ & -2.66 & \\
\hline & MAIPPKKDQDKTEIPAINTIASAEPTVHSTPTTEAVVNA ${ }^{127-165}$ & -2.77 & \\
\hline & AIPPKKDQDKTEIPAINTIASAEPTVH ${ }^{128-154}$ & -2.98 & \\
\hline & MAIPPKKDQDKTEIPAINTIASAEPTVHSTPTTEAVVNAVDNPE ${ }^{127-170}$ & -3.04 & \\
\hline & PPKKDQDKTEIPAINTIASAEPTVHSTPTTEAVVNAVDNPEA ${ }^{129-169}$ & -3.16 & \\
\hline & MAIPPKKDQDKTEIPAINTIASAEPTVHSTPTTEAVVNAVDNPEA ${ }^{127-169}$ & -3.19 & \\
\hline & PPKKDQDKTEEIPAINTIASAEPTV ${ }^{129-153}$ & -3.42 & \\
\hline
\end{tabular}


Table 5. Cont.

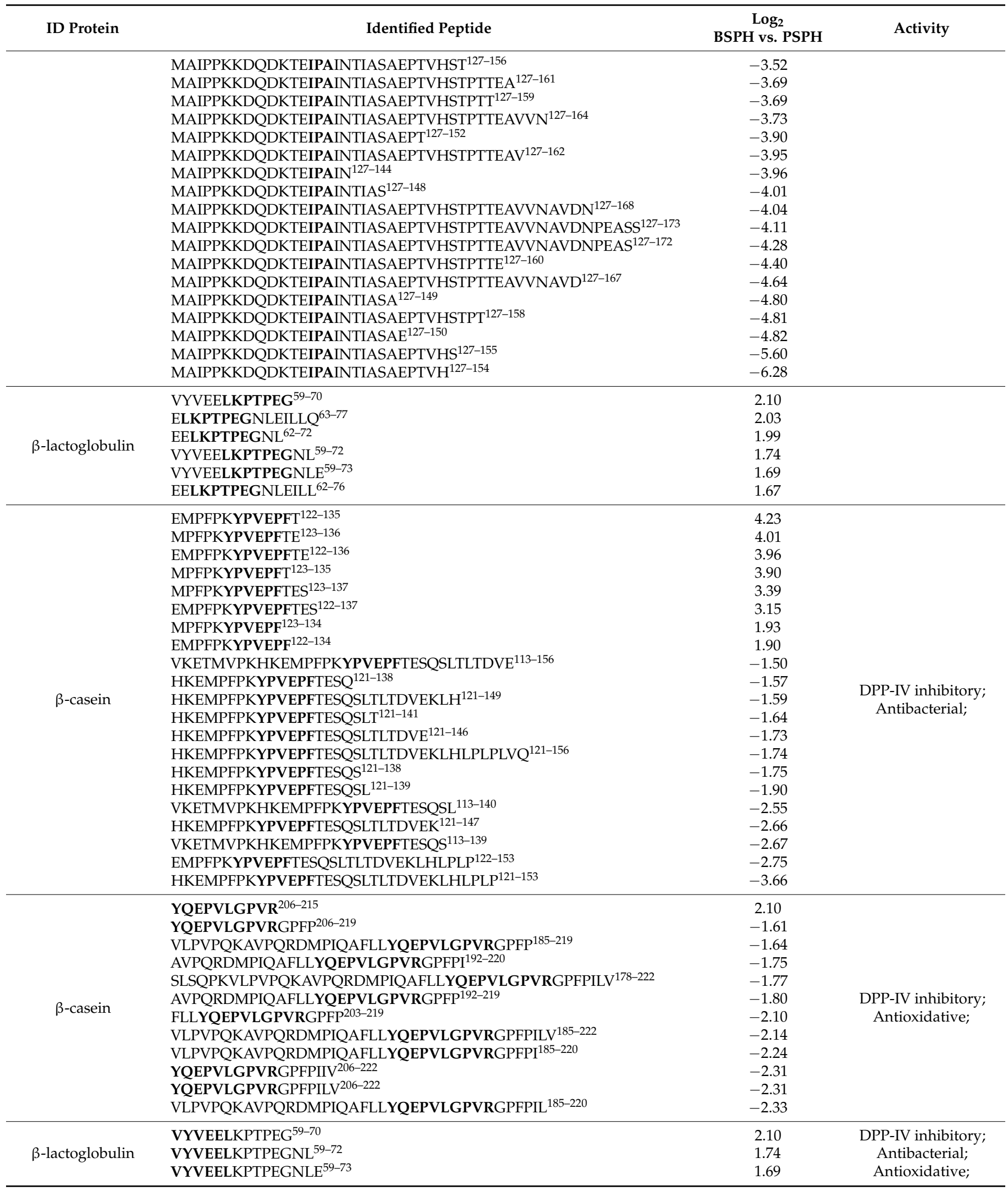


Table 5. Cont.

\begin{tabular}{|c|c|c|c|}
\hline ID Protein & Identified Peptide & $\begin{array}{c}\log _{2} \\
\text { BSPH vs. PSPH }\end{array}$ & Activity \\
\hline$\beta$-lactoglobulin & 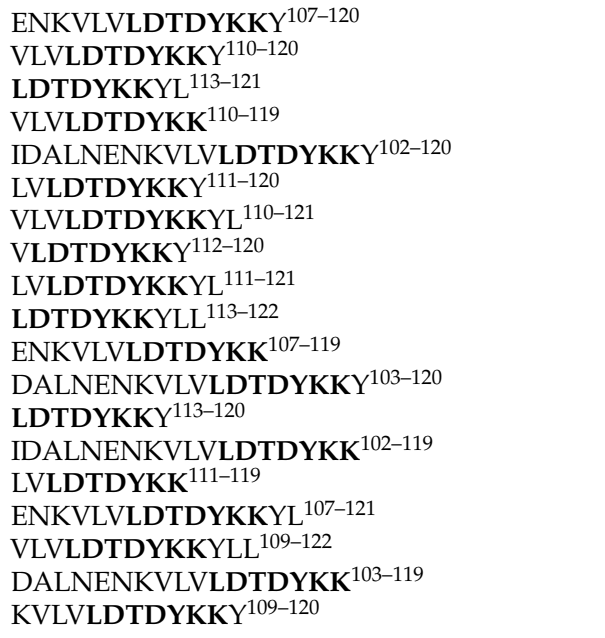 & $\begin{array}{l}3.45 \\
3.42 \\
3.18 \\
3.05 \\
3.05 \\
2.94 \\
2.72 \\
2.62 \\
2.52 \\
2.48 \\
2.48 \\
2.43 \\
2.38 \\
2.33 \\
2.23 \\
2.18 \\
2.17 \\
1.90 \\
1.67\end{array}$ & $\begin{array}{c}\text { DPP-IV inhibitory; } \\
\text { Antibacterial; } \\
\text { Antioxidative; }\end{array}$ \\
\hline$\beta$-lactoglobulin & 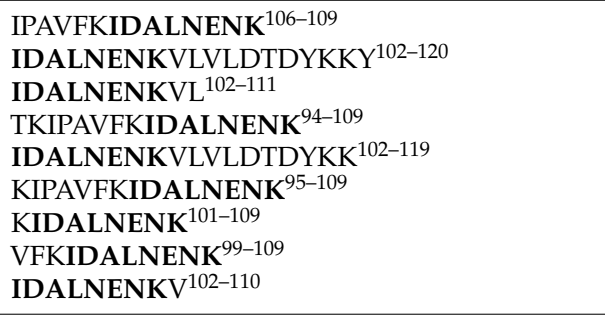 & $\begin{array}{l}3.09 \\
3.05 \\
2.60 \\
2.46 \\
2.33 \\
2.30 \\
2.21 \\
1.99 \\
1.96\end{array}$ & $\begin{array}{l}\text { DPP-IV inhibitory; } \\
\text { Antioxidative; }\end{array}$ \\
\hline$\beta$-lactoglobulin & $\begin{array}{l}\text { IPAVFKIDALNENK } \\
\text { IDALN-109 }^{106} \\
\text { IDALNENKVL }^{102-111} \\
\text { TKIPAVFKIDALNENK } \\
\text { IDALN-109 }^{102-120} \\
\text { KIPAVFKIDALNENK }^{95-109} \\
\text { KIDALNENK }^{101-109} \\
\text { VFKIDALNENK }^{99-109} \\
\text { IDALNENKV }^{102-110}\end{array}$ & $\begin{array}{l}3.09 \\
3.05 \\
2.60 \\
2.46 \\
2.33 \\
2.30 \\
2.21 \\
1.99 \\
1.96\end{array}$ & $\begin{array}{l}\text { DPP-IV inhibitory; } \\
\text { Antioxidative; }\end{array}$ \\
\hline$\beta$-lactoglobulin & $\begin{array}{l}\text { IPAVFKIDALNENK } \\
\text { IDALN-109 }^{106} \\
\text { IDALNENKVL }^{102-111} \\
\text { TKIPAVFKIDALNENK } \\
\text { IDA-109 } \\
\text { KIPAVFKIDALNENKNKN }^{95-109} \\
\text { KIDALNENK }^{101-109} \\
\text { VFKIDALNENK }^{99-109} \\
\text { IDALNENKV }^{102-110}\end{array}$ & $\begin{array}{l}3.09 \\
3.05 \\
2.60 \\
2.46 \\
2.33 \\
2.30 \\
2.21 \\
1.99 \\
1.96\end{array}$ & $\begin{array}{l}\text { DPP-IV inhibitory; } \\
\text { Antioxidative; }\end{array}$ \\
\hline$\beta$-lactoglobulin & $\begin{array}{l}\text { LDIQKVAGTWHS } \\
\text { IIVT-39 } \\
\text { IITMKGLDIQKVAGTWH }\end{array}$ & $\begin{array}{c}1.92 \\
-2.06\end{array}$ & $\begin{array}{l}\text { DPP-IV inhibitory; } \\
\text { Antioxidative; }\end{array}$ \\
\hline$\beta$-lactoglobulin & $\begin{array}{l}\text { AASDISLLDAQSAPLR } \\
\text { LAMAAS-58 }^{43} \\
\text { MAASDISLLDAQSAPLR } \\
\text { AA-58 } \\
\text { AASDISLLDAQSAPLRV }\end{array}$ & $\begin{array}{l}2.57 \\
2.37 \\
1.88 \\
1.53\end{array}$ & $\begin{array}{l}\text { DPP-IV inhibitory; } \\
\text { Antibacterial; }\end{array}$ \\
\hline$\beta$-lactoglobulin & $\begin{array}{l}\text { TPEVDNEALEKFDKALK } \\
\text { TPEVDN-159 } \\
\text { DNEALEKFDKALK }^{147-159} \\
\text { EVDNEALEKFDKALK }^{145-169} \\
\text { NEALEKFDKALK }^{148-159} \\
\text { EALEKFDKALKALPMH }^{149-164} \\
\text { NEALEKFDKALKALPMH } \\
\text { NEALEKFDKALKALPMHIR } \\
\text { EA-164-166 } \\
\text { EALEKFDKALKALPMHIR }\end{array}$ & $\begin{array}{c}4.03 \\
2.92 \\
2.38 \\
2.01 \\
-1.62 \\
-1.77 \\
-2.37 \\
-2.65 \\
-2.96\end{array}$ & $\begin{array}{l}\text { DPP-IV inhibitory; } \\
\text { Antioxidative; }\end{array}$ \\
\hline
\end{tabular}

The active sequences contained in longer peptides are highlighted with bold characters. 


\section{Conclusions}

Due to its higher content of nutrients compared to other species, ovine scotta is a precious substrate that can be valorized through a multidisciplinary biotechnological approach with the aim of producing ingredients with specific biological activities. The enzymatic hydrolyses performed both with bromelain and pancreatin on retentate of scotta allowed enhancement of its DPP-IV inhibitory and antioxidant activities, bromelain being more promising in such an aim. Likewise, the antibacterial activity of hydrolysates slightly increased with respect to control, even if an inhibitory effect against some Listeria monocytogenes strains of the non-hydrolysates scotta was also noticed. LC-MS/MS analysis allowed identification among the experimental groups of several differential peptides that contain sequences with known activities among those here studied. Further studies are needed to optimize reaction conditions, in order to maximize such biological activities in relation to the specific objective.

Supplementary Materials: The following are available online at https://www.mdpi.com/article/ 10.3390/foods10123137/s1, Sheet S1: All identified peptides in BSPH, PSHP, and CTRL. Sheet S2: Differential proteins analysis of BSPH vs. CTRL. Sheet S3: Differential peptides analysis of BSPH vs. CTRL. Sheet S4: Differential proteins analysis of PSPH vs. CTRL. Sheet S5: Differential peptides analysis of PSPH vs. CTRL. Sheet S6: Differential proteins analysis of BSPH vs. PSPH. Sheet S7: Differential peptides analysis of BSPH vs. PSPH.

Author Contributions: Conceptualization, P.P.U.; methodology, P.P.U., R.C., F.F., G.L.P.; formal analysis, R.C., F.F., P.P.U., S.P.; investigation, R.C., F.F., R.A., S.P.; resources, P.P.U.; writing-original draft preparation, R.C., P.P.U., F.F., G.L.P.; writing—review and editing, P.P.U., R.C., G.L.P., F.F., D.P., S.P.; supervision, P.P.U. and A.P.; project administration, P.P.U.; funding acquisition, P.P.U. All authors have read and agreed to the published version of the manuscript.

Funding: This research was funded by Regione Autonoma della Sardegna-Legge Regionale 7 agosto 2007, n.7, Bando Capitale Umano ad Alta Qualificazione, annualità 2015 and by Fondo dell'Ateneo di Sassari per la ricerca 2020.

Data Availability Statement: The peptides identified in this study were analyzed for potential activity with the tool available on BIOPEP-UWM database at the following link: https://biochemia. uwm.edu.pl/en/biopep-uwm-2/.

Acknowledgments: The authors would like to thank Nutraceutica SRL and Enzyme Development Corporation for the supply of enzymes, and Caseificio F.lli Pinna (Thiesi, SS) for the scotta samples used in this study.

Conflicts of Interest: The authors declare no conflict of interest.

\section{References}

1. Salvatore, E.; Pes, M.; Falchi, G.; Pagnozzi, D.; Furesi, S.; Fiori, M.; Roggio, T.; Addis, M.F.; Pirisi, A. Effect of whey concentration on protein recovery in fresh ovine ricotta cheese. J. Dairy Sci. 2014, 97, 4686-4694. [CrossRef] [PubMed]

2. Pires, A.F.; Marnotes, N.G.; Rubio, O.D.; Garcia, A.C.; Pereira, C.D. Dairy by-Products: A Review on the Valorization of Whey and Second Cheese Whey. Foods 2021, 10, 1067. [CrossRef]

3. ISTAT Latte e Prodotti Lattiero Caseari: Prodotti per Tipo di Unità Produttiva. Available online: http://dati.istat.it/Index.aspx? QueryId=25267 (accessed on 19 September 2021).

4. Pulina, G.; Milán, M.J.; Lavín, M.P.; Theodoridis, A.; Morin, E.; Capote, J.; Thomas, D.L.; Francesconi, A.H.D.; Caja, G. Invited review: Current production trends, farm structures, and economics of the dairy sheep and goat sectors. J. Dairy Sci. 2018, 101, 6715-6729. [CrossRef] [PubMed]

5. ISTAT Latte e Prodotti Lattiero Caseari: Prodotti-Reg. Available online: http:/ / dati.istat.it/Index.aspx?QueryId=25520 (accessed on 19 September 2021).

6. Sansonetti, S.; Curcio, S.; Calabrò, V.; Iorio, G. Optimization of ricotta cheese whey (RCW) fermentation by response surface methodology. Bioresour. Technol. 2010, 101, 9156-9162. [CrossRef]

7. Carvalho, F.; Prazeres, A.R.; Rivas, J. Cheese whey wastewater: Characterization and treatment. Sci. Total Environ. 2013, 445-446, 385-396. [CrossRef] [PubMed]

8. Mostafa, A.A. Treatment of cheese processing wastewater by physicochemical and biological methods. Int. J. Microbiol. Res. 2013, $4,321-332$ 
9. Monti, L.; Donati, E.; Zambrini, A.V.; Contarini, G. Application of membrane technologies to bovine Ricotta cheese exhausted whey (scotta). Int. Dairy J. 2018, 85, 121-128. [CrossRef]

10. Pintado, M.E.; Macedo, A.C.; Malcata, F.X. Review: Technology, Chemistry and Microbiology of Whey Cheeses. Food Sci. Technol. Int. 2001, 7, 105-116. [CrossRef]

11. Sommella, E.; Pepe, G.; Ventre, G.; Pagano, F.; Conte, G.M.; Ostacolo, C.; Manfra, M.; Tenore, G.C.; Russo, M.; Novellino, E.; et al. Detailed peptide profiling of "Scotta": From a dairy waste to a source of potential health-promoting compounds. Dairy Sci. Technol. 2016, 96, 763-771. [CrossRef]

12. Secchi, N.; Giunta, D.; Pretti, L.; García, M.R.; Roggio, T.; Mannazzu, I.; Catzeddu, P. Bioconversion of ovine scotta into lactic acid with pure and mixed cultures of lactic acid bacteria. J. Ind. Microbiol. Biotechnol. 2012, 39, 175-181. [CrossRef]

13. Ribeiro, J.E.; Martini, M.; Altomonte, I.; Salari, F.; Nardoni, S.; Sorce, C.; Silva, F.L.D.; Andreucci, A. Production of Chlorella protothecoides biomass, chlorophyll and carotenoids using the dairy industry by-product scotta as a substrate. Biocatal. Agric. Biotechnol. 2017, 11, 207-213. [CrossRef]

14. Vincenzi, A.; Maciel, M.J.; Burlani, É.L.; Oliveira, E.C.; Volpato, G.; Lehn, D.N.; de Souza, C.F.V. Ethanol Bio-Production from ricotta cheese whey by several strains of the yeast Kluyveromyces. Am. J. Food Technol. 2014, 9, 281-291. [CrossRef]

15. Monari, S.; Ferri, M.; Russo, C.; Prandi, B.; Tedeschi, T.; Bellucci, P.; Zambrini, A.V.; Donati, E.; Tassoni, A. Enzymatic production of bioactive peptides from scotta, an exhausted by-product of ricotta cheese processing. PLoS ONE 2019, 14, e0226834. [CrossRef]

16. Pontonio, E.; Montemurro, M.; De Gennaro, G.V.; Miceli, V.; Rizzello, C.G. Anthypertensive Peptides from Ultrafiltration and Fermentation of the Ricotta Cheese Exhausted Whey: Design and Characterization of a Functional Ricotta Cheese. Foods 2021, 10, 2573. [CrossRef]

17. Raho, S.; Carofiglio, V.E.; Montemurro, M.; Miceli, V.; Centrone, D.; Stufano, P.; Schioppa, M.; Pontonio, E.; Rizzello, C.G. Production of the polyhydroxyalkanoate PHBV from ricotta cheese exhausted whey by haloferax mediterranei fermentation. Foods 2020, 9, 1459. [CrossRef]

18. Maragkoudakis, P.; Vendramin, V.; Bovo, B.; Treu, L.; Corich, V.; Giacomini, A. Potential use of scotta, the by-product of the ricotta cheese manufacturing process, for the production of fermented drinks. J. Dairy Res. 2016, 83, 104-108. [CrossRef] [PubMed]

19. Vasmara, C.; Marchetti, R. Initial pH influences in-batch hydrogen production from scotta permeate. Int. J. Hydrogen Energy 2017, 42, 14400-14408. [CrossRef]

20. Vasmara, C.; Pindo, M.; Micheletti, D.; Marchetti, R. Initial pH influences microbial communities composition in dark fermentation of scotta permeate. Int. J. Hydrogen Energy 2018, 43, 8707-8717. [CrossRef]

21. Mazorra-Manzano, M.A.; Ramírez-Suarez, J.C.; Yada, R.Y. Plant proteases for bioactive peptides release: A review. Crit. Rev. Food Sci. Nutr. 2018, 58, 2147-2163. [CrossRef] [PubMed]

22. Dinika, I.; Verma, D.K.; Balia, R.; Utama, G.L.; Patel, A.R. Potential of cheese whey bioactive proteins and peptides in the development of antimicrobial edible film composite: A review of recent trends. Trends Food Sci. Technol. 2020, 103, 57-67. [CrossRef]

23. Andler, S.M.; Goddard, J.M. Transforming food waste: How immobilized enzymes can valorize waste streams into revenue streams. NPJ Sci. Food 2018, 2, 19. [CrossRef] [PubMed]

24. Vargas-Bello-Pérez, E.; Márquez-Hernández, R.I.; Hernández-Castellano, L.E. Bioactive peptides from milk: Animal determinants and their implications in human health. J. Dairy Res. 2019, 86, 136-144. [CrossRef] [PubMed]

25. Minj, S.; Anand, S. Whey Proteins and Its Derivatives: Bioactivity, Functionality, and Current Applications. Dairy 2020, 1, 16. [CrossRef]

26. Tulipano, G.; Sibilia, V.; Caroli, A.M.; Cocchi, D. Whey proteins as source of dipeptidyl dipeptidase IV (dipeptidyl peptidase-4) inhibitors. Peptides 2011, 32, 835-838. [CrossRef]

27. Tagliazucchi, D.; Martini, S.; Shamsia, S.; Helal, A.; Conte, A. Biological activities and peptidomic profile of in vitro-digested cow, camel, goat and sheep milk. Int. Dairy J. 2018, 81, 19-27. [CrossRef]

28. Lacroix, I.M.E.; Li-Chan, E.C.Y. Dipeptidyl peptidase-IV inhibitory activity of dairy protein hydrolysates. Int. Dairy J. 2012, 25, 97-102. [CrossRef]

29. Nongonierma, A.B.; Fitzgerald, R.J. Dipeptidyl peptidase IV inhibitory and antioxidative properties of milk protein-derived dipeptides and hydrolysates. Peptides 2013, 39, 157-163. [CrossRef]

30. Ministero della Salute Diabete Mellito Tipo 2. Available online: https://www.salute.gov.it/portale/nutrizione/dettaglioContenutiNutrizione. jsp?lingua=italiano\&id=5511\&area=nutrizione \&menu=croniche (accessed on 12 October 2021).

31. Corrochano, A.R.; Buckin, V.; Kelly, P.M.; Giblin, L. Invited review: Whey proteins as antioxidants and promoters of cellular antioxidant pathways. J. Dairy Sci. 2018, 101, 4747-4761. [CrossRef]

32. El-Zahar, K.; Sitohy, M.; Dalgalarrondo, M.; Choiset, Y.; Métro, F.; Haertlé, T.; Chobert, J.M. Purification and physicochemical characterization of ovine $\beta$-lactoglobulin and $\alpha$-lactalbumin. Food/Nahrung 2004, 48, 177-183. [CrossRef]

33. López-Expósito, I.; Gómez-Ruiz, J.A.; Amigo, L.; Recio, I. Identification of antibacterial peptides from ovine $\alpha$ s2-casein. Int. Dairy J. 2006, 16, 1072-1080. [CrossRef]

34. Atanasova, J.; Ivanova, I. Antibacterial peptides from goat and sheep milk proteins. Biotechnol. Biotechnol. Equip. 2010, 24, 1799-1803. [CrossRef]

35. Lacroix, I.M.E.; Li-Chan, E.C.Y. Food-derived dipeptidyl-peptidase IV inhibitors as a potential approach for glycemic regulationCurrent knowledge and future research considerations. Trends Food Sci. Technol. 2016, 54, 1-16. [CrossRef] 
36. Lestari, P. Suyata Antibacterial activity of hydrolysate protein from Etawa goat milk hydrolysed by crude extract bromelain. IOP Conf. Ser. Mater. Sci. Eng. 2019, 509, 012111. [CrossRef]

37. Cabizza, R.; Rubattu, N.; Salis, S.; Pes, M.; Comunian, R.; Paba, A.; Addis, M.; Testa, M.C.; Urgeghe, P.P. Transfer of oxytetracycline from ovine spiked milk to whey and cheese. Int. Dairy J. 2017, 70, 12-17. [CrossRef]

38. Petretto, G.L.; Maldini, M.; Addis, R.; Chessa, M.; Foddai, M.; Rourke, J.P.; Pintore, G. Variability of chemical composition and antioxidant activity of essential oils between Myrtus communis var. Leucocarpa DC and var. Melanocarpa DC. Food Chem. 2016, 197, 124-131. [CrossRef]

39. Baranyi, J.; Roberts, T.A. A dynamic approach to predicting bacterial growth in food. Int. J. Food Microbiol. 1994, 23, 277-294. [CrossRef]

40. ComBase DMFit for Excel. Available online: https://www.combase.cc/index.php/en/8-category-en-gb/21-tools (accessed on 19 June 2021).

41. Le Maux, S.; Nongonierma, A.B.; FitzGerald, R.J. Peptide composition and dipeptidyl peptidase IV inhibitory properties of $\beta$-lactoglobulin hydrolysates having similar extents of hydrolysis while generated using different enzyme-to-substrate ratios. Food Res. Int. 2017, 99, 84-90. [CrossRef]

42. Old, W.M.; Meyer-Arendt, K.; Aveline-Wolf, L.; Pierce, K.G.; Mendoza, A.; Sevinsky, J.R.; Resing, K.A.; Ahn, N.G. Comparison of label-free methods for quantifying human proteins by shotgun proteomics. Mol. Cell. Proteom. 2005, 4, 1487-1502. [CrossRef] [PubMed]

43. Pisanu, S.; Cacciotto, C.; Pagnozzi, D.; Puggioni, G.M.G.; Uzzau, S.; Ciaramella, P.; Guccione, J.; Penati, M.; Pollera, C.; Moroni, P.; et al. Proteomic changes in the milk of water buffaloes (Bubalus bubalis) with subclinical mastitis due to intramammary infection by Staphylococcus aureus and by non-aureus staphylococci. Sci. Rep. 2019, 9, 15850. [CrossRef] [PubMed]

44. Minkiewicz, P.; Iwaniak, A.; Darewicz, M. BIOPEP-UWM Database of Bioactive Peptides: Current Opportunities. Int. J. Mol. Sci. 2019, 20, 5978. [CrossRef] [PubMed]

45. Liu, R.; Cheng, J.; Wu, H. Discovery of food-derived dipeptidyl peptidase IV inhibitory peptides: A review. Int. J. Mol. Sci. 2019, 20, 463. [CrossRef] [PubMed]

46. Nongonierma, A.B.; FitzGerald, R.J. Dipeptidyl peptidase IV inhibitory properties of a whey protein hydrolysate: Influence of fractionation, stability to simulated gastrointestinal digestion and food-drug interaction. Int. Dairy J. 2013, 32, 33-39. [CrossRef]

47. Song, J.J.; Wang, Q.; Du, M.; Ji, X.M.; Mao, X.Y. Identification of dipeptidyl peptidase-IV inhibitory peptides from mare whey protein hydrolysates. J. Dairy Sci. 2017, 100, 6885-6894. [CrossRef] [PubMed]

48. Konrad, B.; Anna, D.; Marek, S.; Marta, P.; Aleksandra, Z.; Józefa, C. The Evaluation of Dipeptidyl Peptidase (DPP)-IV, $\alpha$ Glucosidase and Angiotensin Converting Enzyme (ACE) Inhibitory Activities of Whey Proteins Hydrolyzed with Serine Protease Isolated from Asian Pumpkin (Cucurbita ficifolia). Int. J. Pept. Res. Ther. 2014, 20, 483-491. [CrossRef] [PubMed]

49. Lacroix, I.M.E.; Li-Chan, E.C.Y. Inhibition of dipeptidyl peptidase (DPP)-IV and $\alpha$-glucosidase activities by pepsin-treated whey proteins. J. Agric. Food Chem. 2013, 61, 7500-7506. [CrossRef]

50. Power, O.; Nongonierma, A.B.; Jakeman, P.; FitzGerald, R.J. Food protein hydrolysates as a source of dipeptidyl peptidase IV inhibitory peptides for the management of type 2 diabetes. Proc. Nutr. Soc. 2014, 73, 34-46. [CrossRef]

51. Corrêa, A.P.F.; Daroit, D.J.; Fontoura, R.; Meira, S.M.M.; Segalin, J.; Brandelli, A. Hydrolysates of sheep cheese whey as a source of bioactive peptides with antioxidant and angiotensin-converting enzyme inhibitory activities. Peptides 2014, 61, 48-55. [CrossRef]

52. Nongonierma, A.B.; FitzGerald, R.J. Enzymes Exogenous to Milk in Dairy Technology: Proteinases. Encycl. Dairy Sci. Second Ed. 2011, 2, 289-296. [CrossRef]

53. Biziulevičius, G.A.; Kislukhina, O.V.; Kazlauskaite, J.; Žukaite, V. Food-protein enzymatic hydrolysates possess both antimicrobial and immunostimulatory activities: A "cause and effect" theory of bifunctionality. FEMS Immunol. Med. Microbiol. 2006, 46, 131-138. [CrossRef]

54. Tulipano, G.; Faggi, L.; Nardone, A.; Cocchi, D.; Caroli, A.M. Characterisation of the potential of $\beta$-lactoglobulin and $\alpha$ lactalbumin as sources of bioactive peptides affecting incretin function: In silico and in vitro comparative studies. Int. Dairy J. 2015, 48, 66-72. [CrossRef]

55. Uenishi, H.; Kabuki, T.; Seto, Y.; Serizawa, A.; Nakajima, H. Isolation and identification of casein-derived dipeptidyl-peptidase 4 (DPP-4)-inhibitory peptide LPQNIPPL from gouda-type cheese and its effect on plasma glucose in rats. Int. Dairy J. 2012, 22, 24-30. [CrossRef]

56. Otte, J.; Shalaby, S.M.; Zakora, M.; Pripp, A.H.; El-Shabrawy, S.A. Angiotensin-converting enzyme inhibitory activity of milk protein hydrolysates: Effect of substrate, enzyme and time of hydrolysis. Int. Dairy J. 2007, 17, 488-503. [CrossRef]

57. Sandré, C.; Gleizes, A.; Forestier, F.; Gorges-Kergot, R.; Chilmonczyk, S.; Léonil, J.; Moreau, M.-C.; Labarre, C. A peptide derived from bovine $\beta$-casein modulates functional properties of bone marrow-derived macrophages from germfree and human flora-associated mice. J. Nutr. 2001, 131, 2936-2942. [CrossRef] [PubMed]

58. Silva, S.V.; Malcata, F.X. Caseins as source of bioactive peptides. Int. Dairy J. 2005, 15, 1-15. [CrossRef]

59. Balthazar, C.F.; Pimentel, T.C.; Ferrão, L.L.; Almada, C.N.; Santillo, A.; Albenzio, M.; Mollakhalili, N.; Mortazavian, A.M.; Nascimento, J.S.; Silva, M.C.; et al. Sheep Milk: Physicochemical Characteristics and Relevance for Functional Food Development. Compr. Rev. Food Sci. Food Saf. 2017, 16, 247-262. [CrossRef] 
60. Sowmya, K.; Bhat, M.I.; Bajaj, R.K.; Kapila, S.; Kapila, R. Buffalo Milk Casein Derived Decapeptide (YQEPVLGPVR) Having Bifunctional Anti-inflammatory and Antioxidative Features under Cellular Milieu. Int. J. Pept. Res. Ther. 2019, 25, 623-633. [CrossRef]

61. Nielsen, S.D.; Beverly, R.L.; Underwood, M.A.; Dallas, D.C. Release of functional peptides from mother's milk and fortifier proteins in the premature infant stomach. PLoS ONE 2018, 13, e0208204. [CrossRef]

62. Liu, H.; Tu, M.; Cheng, S.; Chen, H.; Wang, Z.; Du, M. An anticoagulant peptide from beta-casein: Identification, structure and molecular mechanism. Food Funct. 2019, 10, 886-892. [CrossRef]

63. Hao, X.; Yang, W.; Zhu, Q.; Zhang, G.; Zhang, X.; Liu, L.; Li, X.; Hussain, M.; Ni, C.; Jiang, X. Proteolysis and ACE-inhibitory peptide profile of Cheddar cheese: Effect of digestion treatment and different probiotics. LWT 2021, 145, 111295. [CrossRef]

64. Murray, N.M.; O’Riordan, D.; Jacquier, J.C.; O'Sullivan, M.; Holton, T.A.; Wynne, K.; Robinson, R.C.; Barile, D.; Nielsen, S.D.; Dallas, D.C. Peptidomic screening of bitter and nonbitter casein hydrolysate fractions for insulinogenic peptides. J. Dairy Sci. 2018, 101, 2826-2837. [CrossRef] [PubMed]

65. Nongonierma, A.B.; Fitzgerald, R.J. Structure activity relationship modelling of milk protein-derived peptides with dipeptidyl peptidase IV (DPP-IV) inhibitory activity. Peptides 2016, 79, 1-7. [CrossRef]

66. Jiang, B.; Zhang, X.; Yuan, Y.; Qu, Y.; Feng, Z. Separation of antioxidant peptides from pepsin hydrolysate of whey protein isolate by ATPS of EOPO Co-polymer (UCON)/Phosphate. Sci. Rep. 2017, 7, 13320. [CrossRef]

67. Mann, B.; Kumari, A.; Kumar, R.; Sharma, R.; Prajapati, K.; Mahboob, S.; Athira, S. Antioxidant activity of whey protein hydrolysates in milk beverage system. J. Food Sci. Technol. 2015, 52, 3235-3241. [CrossRef]

68. Pellegrini, A.; Dettling, C.; Thomas, U.; Hunziker, P. Isolation and characterization of four bactericidal domains in the bovine ß-lactoglobulin. Biochim. Biophys. Acta Gen. Subj. 2001, 1526, 131-140. [CrossRef]

69. Elbarbary, H.A.; Ejima, A.; Sato, K. Generation of antibacterial peptides from crude cheese whey using pepsin and rennet enzymes at various pH conditions. J. Sci. Food Agric. 2019, 99, 555-563. [CrossRef]

70. Worsztynowicz, P.; Białas, W.; Grajek, W. Integrated approach for obtaining bioactive peptides from whey proteins hydrolysed using a new proteolytic lactic acid bacteria. Food Chem. 2020, 312, 126035. [CrossRef]

71. Chatterjee, A.; Kanawjia, S.K.; Khetra, Y.; Saini, P. Discordance between in silico \& in vitro analyses of ACE inhibitory \& antioxidative peptides from mixed milk tryptic whey protein hydrolysate. J. Food Sci. Technol. 2015, 52, 5621-5630. [CrossRef]

72. Conway, V.; Gauthier, S.F.; Pouliot, Y. Antioxidant activities of buttermilk proteins, whey proteins, and their enzymatic hydrolysates. J. Agric. Food Chem. 2013, 61, 364-372. [CrossRef]

73. Nongonierma, A.B.; FitzGerald, R.J. Strategies for the discovery and identification of food protein-derived biologically active peptides. Trends Food Sci. Technol. 2017, 69, 289-305. [CrossRef]

74. Lacroix, I.M.E.; Li-Chan, E.C.Y. Isolation and characterization of peptides with dipeptidyl peptidase-IV inhibitory activity from pepsin-treated bovine whey proteins. Peptides 2014, 54, 39-48. [CrossRef]

75. Silveira, S.T.; Martínez-Maqueda, D.; Recio, I.; Hernández-Ledesma, B. Dipeptidyl peptidase-IV inhibitory peptides generated by tryptic hydrolysis of a whey protein concentrate rich in $\beta$-lactoglobulin. Food Chem. 2013, 141, 1072-1077. [CrossRef]

76. Power, O.; Fernández, A.; Norris, R.; Riera, F.A.; FitzGerald, R.J. Selective enrichment of bioactive properties during ultrafiltration of a tryptic digest of $\beta$-lactoglobulin. J. Funct. Foods 2014, 9, 38-47. [CrossRef]

77. Bella, A.M.; Erickson, R.H.; Kim, Y.S. Rat intestinal brush border membrane dipeptidyl-aminopeptidase IV: Kinetic properties and substrate specificities of the purified enzyme. Arch. Biochem. Biophys. 1982, 218, 156-162. [CrossRef]

78. Ji, W.; Zhang, C.; Ji, H. Purification, identification and molecular mechanism of two dipeptidyl peptidase IV (DPP-IV) inhibitory peptides from Antarctic krill (Euphausia superba) protein hydrolysate. J. Chromatogr. B Anal. Technol. Biomed. Life Sci. 2017, 1064, 56-61. [CrossRef]

79. Ouertani, A.; Chaabouni, I.; Mosbah, A.; Long, J.; Barakat, M.; Mansuelle, P.; Mghirbi, O.; Najjari, A.; Ouzari, H.I.; Masmoudi, A.S.; et al. Two new secreted proteases generate a casein-derived antimicrobial peptide in Bacillus cereus food born isolate leading to bacterial competition in milk. Front. Microbiol. 2018, 9, 1148. [CrossRef]

80. Bounouala, F.Z.; Roudj, S.; Karam, N.E.; Recio, I.; Miralles, B. Casein Hydrolysates by Lactobacillus brevis and Lactococcus lactis Proteases: Peptide Profile Discriminates Strain-Dependent Enzyme Specificity. J. Agric. Food Chem. 2017, 65, 9324-9332. [CrossRef]

81. FitzGerald, R.J.; Cermeño, M.; Khalesi, M.; Kleekayai, T.; Amigo-Benavent, M. Application of in silico approaches for the generation of milk protein-derived bioactive peptides. J. Funct. Foods 2020, 64, 103636. [CrossRef]

82. Hernández-Ledesma, B.; Dávalos, A.; Bartolomé, B.; Amigo, L. Preparation of antioxidant enzymatic hydrolysates from $\alpha-$ lactalbumin and $\beta$-lactoglobulln. Identification of active peptides by HPLC-MS/MS. J. Agric. Food Chem. 2005, 53, 588-593. [CrossRef]

83. Almaas, H.; Eriksen, E.; Sekse, C.; Comi, I.; Flengsrud, R.; Holm, H.; Jensen, E.; Jacobsen, M.; Langsrud, T.; Vegarud, G.E. Antibacterial peptides derived from caprine whey proteins, by digestion with human gastrointestinal juice. Br. J. Nutr. 2011, 106, 896-905. [CrossRef]

84. Contreras, M. del M.; Hernández-Ledesma, B.; Amigo, L.; Martín-Álvarez, P.J.; Recio, I. Production of antioxidant hydrolyzates from a whey protein concentrate with thermolysin: Optimization by response surface methodology. LWT Food Sci. Technol. 2011, 44, 9-15. [CrossRef] 
85. Demers-Mathieu, V.; Gauthier, S.F.; Britten, M.; Fliss, I.; Robitaille, G.; Jean, J. Antibacterial activity of peptides extracted from tryptic hydrolyzate of whey protein by nanofiltration. Int. Dairy J. 2013, 28, 94-101. [CrossRef]

86. Théolier, J.; Hammami, R.; Labelle, P.; Fliss, I.; Jean, J. Isolation and identification of antimicrobial peptides derived by peptic cleavage of whey protein isolate. J. Funct. Foods 2013, 5, 706-714. [CrossRef] 